Fluvial Sediment in

Salem Fork Watershed,

West Virginia

GEOLOGICAL SURVEY WATER-SUPPLY PAPER 1798-K

Prepared in cooperation with the U.S. Department of Agriculture Soil Conservation Service

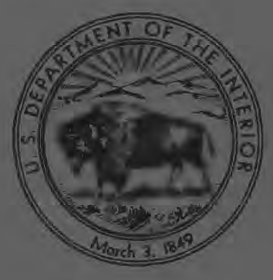




\section{Fluvial Sediment in \\ Salem Fork Watershed, \\ West Virginia}

By RUSSELL F. FLINT

SEDIMENTATION IN SMALL DRAINAGE BASINS

GEOLOGICAL SURVEY WATER-SUPPLY PAPER 1798-K

Prepared in cooperation with the

U.S. Department of Agriculture

Soil Conservation Service

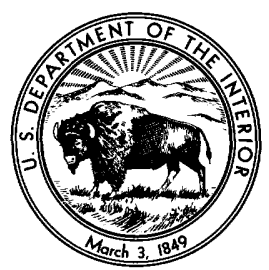




\section{UNITED STATES DEPARTMENT OF THE INTERIOR}

ROGERS C. B. MORTON, Secretary

\section{GEOLOGICAL SURVEY}

V. E. McKELVEY, Director

Library of Congress catalog-card No. 72-600024

For sale by the Superintendent of Documents, U.S. Government Printing Office Washington, D.C. 20402 - Price 30 cents (paper cover)

Stock Number 2401-2165 


\section{CONTENTS}

Abstract.

Introduction

Acknowledgments.

Environmental factors.

Climate

Geology.

Soils and land use

Hydraulic structures.

Runoff..

Fluvial sediment.

Reservoir 11A

Suspended sediment

Deposited sediment, trap efficiency, and sediment yield.

Reservoir 9, suspended sediment.

Salem Fork at Salem, suspended sediment..

\section{ILLUSTRATIONS}

Figure 1. Map showing area of the Salem Fork watershed evaluation project in western Harrison County

2. Photograph of reservoir 9 in Salem Fork watershed, showing structural rock benches.

3. Photograph of Varner Hollow, looking upstream beyond reservoir $11 \mathrm{~A}$ construction site.

4. Map of Salem Fork watershed, showing generalized use-capability classes of the land

5. Photograph of upstream face of detention dam of reservoir 11A, showing outlet works, stage-recorder house, and gage-well intakes.

6. Photograph of reservoir 11A, showing part of emergency spillway

7. Photograph of downstream face of dam of reservoir $11 \mathrm{~A}$, showing outlet pipe and riprap section.....

8. Graph showing average relations of suspendedsediment discharge to water discharge.

9. Graph showing duration curves of daily flow for the two 4-year periods of investigation. 


\section{TABLES}

TABLE 1. Stage and capacity of reservoir $11 \mathrm{~A}$ from survey made in the fall of 1954 .

Page

2. Stage and capacity of reservoir 9 from survey made in November 1956.

3. Water discharge and miscellaneous reservoir computations, subwatersheds $11 \mathrm{~A}$ and 9 and

Salem Fork at Salem

4. Summary of outflow from reservoir 11A, 1954-62

5. Monthly water and sediment discharges, reservoir $11 \mathrm{~A}$

6. Particle-size analyses of suspended sediment, inflow to reservoir $11 \mathrm{~A}$.

7. Particle-size analyses of suspended sediment, outflow from reservoir $11 \mathrm{~A}$

8. Chemical analyses of water in Salem Fork basin.

9. Sediment data for periods between surveys of reservoir $11 \mathrm{~A}$

10. Particle-size analyses of suspended sediment, inflow to and outflow from reservoir 9

11. Particle-size analyses of suspended sediment, Salem Fork at Salem 


\title{
FLUVIAL SEDIMENT IN SALEM FORK WATERSHED, WEST VIRGINIA
}

\author{
By Russell F. Flint
}

\section{ABSTRACT}

Suspended sediment discharged from the 8.32-square-mile Salem Fork study area in Harrison County, W. Va., averaged 3,500 tons per year during the first 4-year period of investigation and 1,770 tons per year during the second 4-year period. The difference was attributed to increased flow control, effected by the completion of detention structures and other conservation measures, the absence of appreciable sediment-producing construction activities, and a reduction of the amounts of rainfall and runoff during the second 4-year period.

Particle-size distribution of the suspended sediment discharged from the watershed remained unchanged during the two 4-year periods. Although sand and some silt were deposited in upstream reservoirs, sands and other sediments were evidently entrained in the flow below the reservoirs.

During the 7.75-year period, reservoir $11 \mathrm{~A}$ had a trap efficiency of 88 percent. The average annual sediment yield of subwatershed $11 \mathrm{~A}$ was 1.31 tons per acre, or 837 tons per square mile. Outflow from reservoir 11A occurred during 81 percent of the investigation period, October 1954 to June 1962, and 78 percent of the sediment discharge from the reservoir occurred during less than 6 percent of the investigation period. A comparison of particle-size distribution of inflow sediment with that of outflow sediment revealed that practically all sands and some silts entering reservoir $11 \mathrm{~A}$ were deposited in the reservoir. Chemical analyses of inflow water and the particle-size analyses suggested that flocculation of fine sediments occurred in the reservoir.

Analysis of the sediment data collected at the outflow of reservoir 9 during 1956-62 revealed that the average annual sediment discharge was 128,000 pounds per year. Limited particle-size data suggested that practically no sand was discharged from reservoir 9 , even though the inflow contained sand.

Average annual inflow to reservoirs $11 \mathrm{~A}$ and 9 compared favorably with average annual runoff for the entire watershed-study area.

\section{INTRODUCTION}

The Salem Fork watershed-evaluation project in Harrison County (fig. 1) was started in 1954 under the direction of the 
U.S. Department of Agriculture, Soil Conservation Service, to evaluate the physical and economic effects of a watershed-protection program.

As part of the overall physical evaluation of the watershed area, the U.S. Geological Survey, in cooperation with the Soil Conservation Service, began to investigate streamflow and sedimentation on October 1,1954 . The investigations were designed

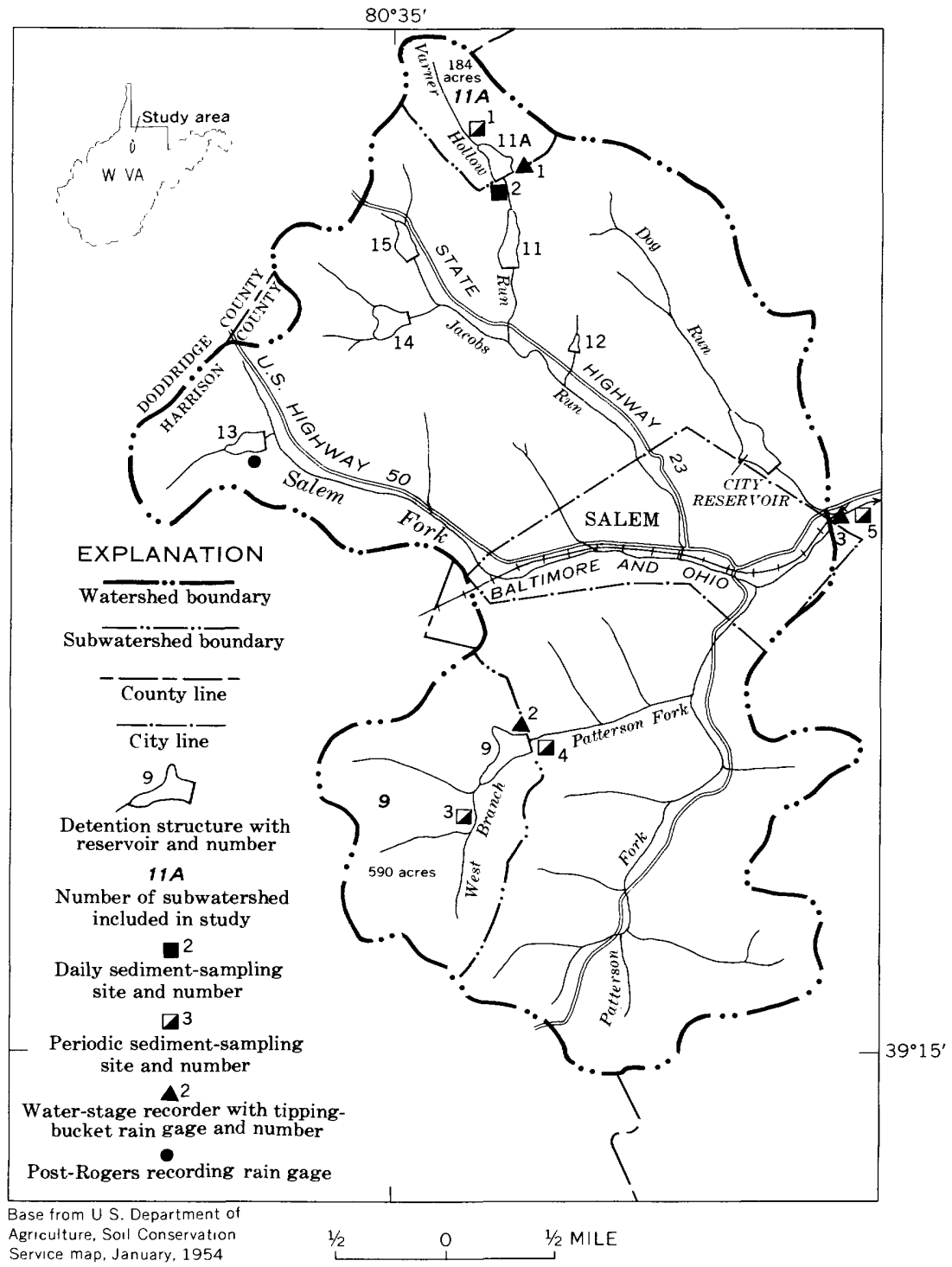

FIgURE 1. - Area of the Salem Fork watershed evaluation project in western Harrison County. 
to yield continuous data on streamflow and periodic data on discharge and particle-size characteristics of suspended sediment at two locations, Salem Fork at Salem, which has a drainage area of $8.32 \mathrm{sq} \mathrm{mi} \mathrm{(square} \mathrm{miles),} \mathrm{and} \mathrm{Salem} \mathrm{Fork} \mathrm{subwatershed} \mathrm{11A}$ (Varner Hollow Run) near Salem, which has a drainage area of $0.288 \mathrm{sq}$ mi. (See fig. 1.) In February 1955, subwatershed 11A was selected as one station in a national network of sediment stations established to determine the trap efficiency of small floodwaterretarding basins. A daily record of sediment discharges from the reservoir and the collection of suspended-sediment samples in the inflow channel were started.

The collection of continuous streamflow and periodic suspendedsediment data at Salem Fork subwatershed 9 (West Branch Patterson Fork) near Salem, which has a drainage area 0.92 sq mi, was started January 25, 1956 (fig. 1). The suspendedsediment data at reservoir 9 provide an index of the watersediment discharge relationship. Limited suspended-sediment data were also collected at the inflow of reservoir 9 for reasons similar to those mentioned for reservoir 11A.

The streamflow station at Salem Fork at Salem was established January 1, 1951, with support from the Federal Inter-Agency River Basin Committee, and continued under this arrangement through the study period. Streamflow from the entire study area was measured at this station.

This report summarizes and interprets the basic sediment and chemical-quality data collected for each drainage area studied as part of the Salem Fork watershed evaluation project and presents sediment-yield and trap-efficiency figures for reservoir 11A. The report includes supplementary hydrologic characteristics of reservoirs $11 \mathrm{~A}$ and 9 and their respective subwatershed areas.

No other reports of similar investigations in this area are available; however, Mundorff (1964) reported the results of a similar investigation conducted during $1955-61$ in Kiowa Creek basin in northeastern Colorado.

\section{ACKNOWLEDGMENTS}

R. E. Quilliam, State conservationist, Soil Conservation Service, provided data on soil descriptions and rainfall in the project area. John W. Roehl, geologist, Soil Conservation Service, provided data on stage-capacity relations for reservoir $11 \mathrm{~A}$, and a summary of current data for reservoir $11 \mathrm{~A}$. 


\section{ENVIRONMENTAL FACTORS}

The Salem Fork basin lies in western Harrison County and is included on 7.5-minute topographic maps of the Salem and Big Isaac quadrangles. Salem Fork rises near the west edge of the county and flows east into Tenmile Creek, a tributary of the West Fork River, which is a tributary of the Monongahela River. The Salem Fork watershed project area (fig. 1), 8.32 $\mathrm{sq} \mathrm{mi}(5,325$ acres $)$, is in the headwaters of the Salem Fork basin and includes those areas drained by Patterson Fork in the south and Jacobs Run and Dog Run in the north. The town of Salem, whose population is 2,510, lies near the center of the area, about 14 miles west of Clarksburg.

The area is served by east-west U.S. Highway 50, which passes along the main street of Salem. State Highway 23 follows Jacobs Run, enters Salem from the northwest, and terminates near the center of town. A paved county highway follows Patterson Fork before entering Salem from the south. A main line of the Baltimore and Ohio Railroad parallels Salem Fork and U.S. Highway 50 as it passes through Salem.

The area, part of the unglaciated Allegheny Mountain section of the Appalachian Plateaus physiographic province (Fenneman, 1938 , p. 283), has rugged topography. Elevations range from about 1,030 feet above sea level near the mouth of Dog Run to about 1,500 feet in the extreme southern and western parts of the area. Hillside slopes are long and steep, but some are broken by structural rock benches as shown in figure 2 . Thornbury (1954, p. 112) attributed the formation of such benches to the alternating weak and strong underlying strata.

\section{CLIMATE}

The climate in the Salem-Clarksburg area is temperate and of the humid-continental type. Clarksburg's mean annual precipitation of about 42 inches is fairly evenly distributed throughout the year. However, high-intensity rainstorms are common during June and July. Many of these storms are cloudbursts and cause flash flooding. The rugged topography of the area includes many small drainage basins which are subject to frequent severe flash flooding. Snow, which constitutes about 20 to 25 percent of the winter precipitation, averages about 25 inches annually and occurs mostly between December and April (Weedfall, no date).

Mean daily temperatures range from a minimum of $22^{\circ} \mathrm{F}$ for January to a maximum of $87^{\circ} \mathrm{F}$ for July. The lowest recorded temperature for Clarksburg was $-32^{\circ} \mathrm{F}$ in February 1932, and 
the highest temperature, $102^{\circ} \mathrm{F}$, occurred in July 1934 and September 1953. The length of frost-free season averages about 150 days but varies owing to differences in elevation (U.S. Dept. Agriculture, 1954, p. 2).

Pan-evaporation data collected at Clarksburg indicate average evaporation ranging from about 2 inches in October to 5.5 inches in July (U.S. Dept. Commerce, 1965) and an average annual lake evaporation of about 30 inches (Kohler and others, 1959).

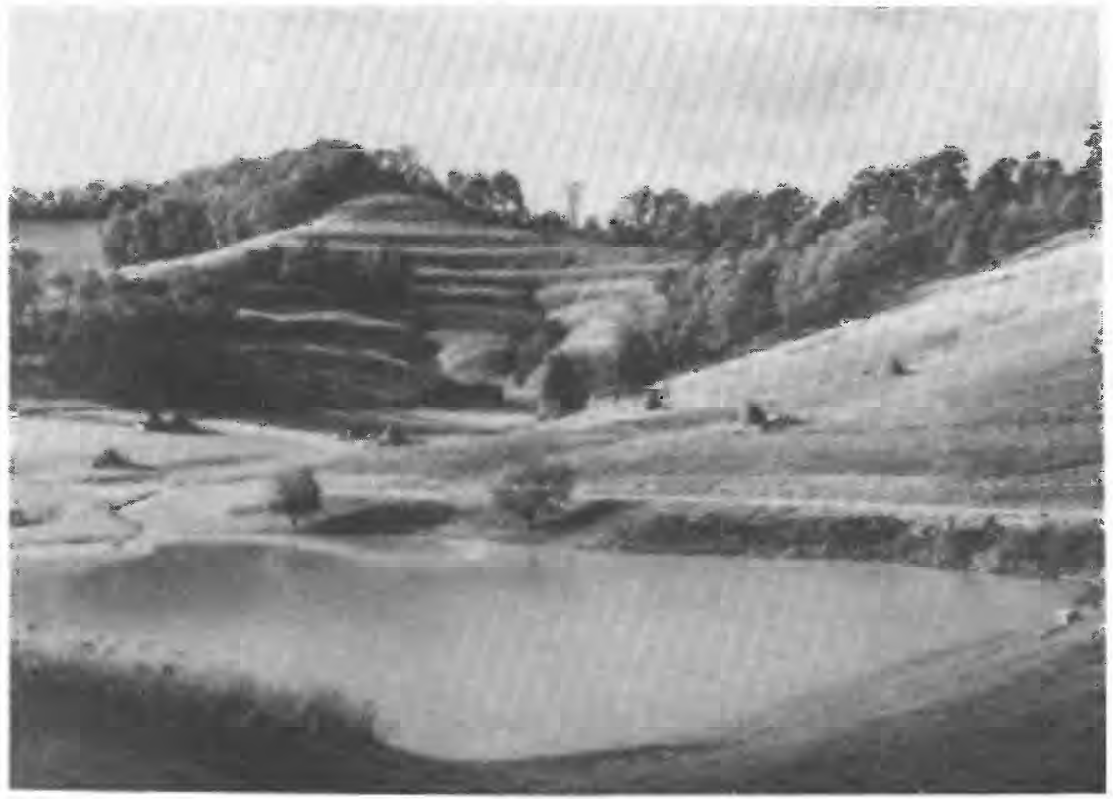

Figune 2. - View of reservoir 9 in Salem Fork watershed, showing structural rock benches which break the long hillside slopes of the area. Photograph reprinted by permission of West Virginia Chamber of Commerce.

\section{GEOLOGY}

The Salem area is strongly dissected. The hills are worn down and rounded by erosion. Ridge skylines are irregular, and there are many gaps in the watershed divides (fig. 3).

The rocks which underlie the area were formed during the Permian and Pennsylvanian Periods of the Paleozoic Era. Nace and Bieber (1958, p. 24) stated that these rocks, collectively called the Dunkard Group, are the youngest sedimentary rocks in West Virginia. The group is composed of interstratified gray, green, and brown sandstone, red and varicolored sandy or limy shale, black carbonaceous shale, limestone, and impure coal. Two 
formations of the Dunkard Group, the Greene and the Washington, are in the Salem area. The Proctor Sandstone of White (1883), the topmost unit of the Greene Formation, caps some of the higher hills of the area; rocks of the Washington Formation are about 600 feet below the Proctor Sandstone (Nace and Bieber, 1958, p. 17). The relief of the area indicates that rocks of the Greene Formation make up the principal parent materials for the soils of the Salem area.

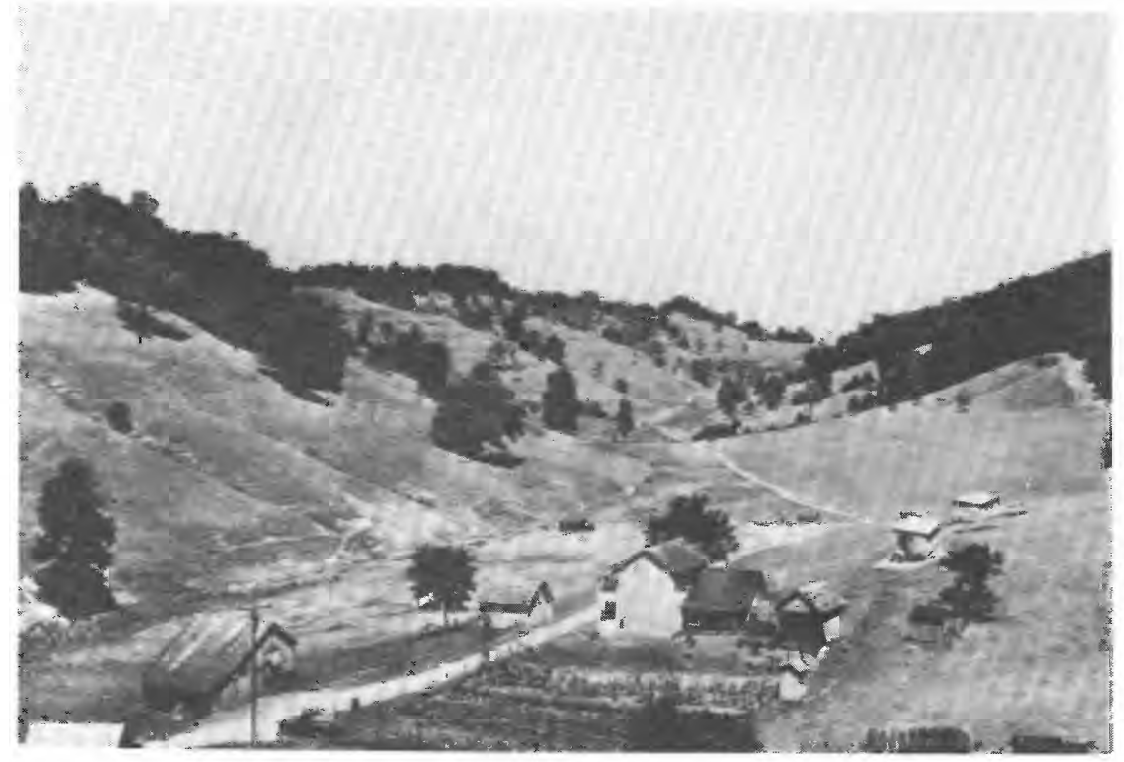

Figure 3. - View of Varner Hollow, looking upstream beyond reservoir 11A construction site and showing dissected area and irregular skyline which is typical of the area. Photograph by Soil Conservation Service.

\section{SOILS AND LAND USE}

The soils of the upland areas of the Salem Fork watershed are part of the Upshur-Gilpin complex, a result of the erosion and intermingling of the Upshur and Gilpin soils. Vandalia soils occur on the footslopes, and Moshannon, Senecaville, and Melvin soils make up the bottom lands (R. E. Quilliam, written commun., 1970). The Upshur soils are moderately deep or deep, well drained, and clayey; the Gilpin soils are loamy, moderately deep, gently sloping to very steep, and well drained (Beverage and others, 1968). Vandalia soils are typically deep and well drained, and their subsoil textures range from silty clay to clay. The deep Moshannon, Senecaville, and Melvin soils, formed from alluvium washed into the bottom lands from upland areas, are 
well drained, moderately well drained, and poorly drained, respectively. Their textures range from silt loam to silty clay loam (Gorman and Rayburn, 1961).

Detailed acreage figures are not available for the different soils of the watershed; however, the land of the watershed was divided into capability classes by the Soil Conservation Service in 1954. Figure 4 shows this classification. Less than 9 percent of the land comprised classes $1,2 w$, and $3 e$ and was suitable for

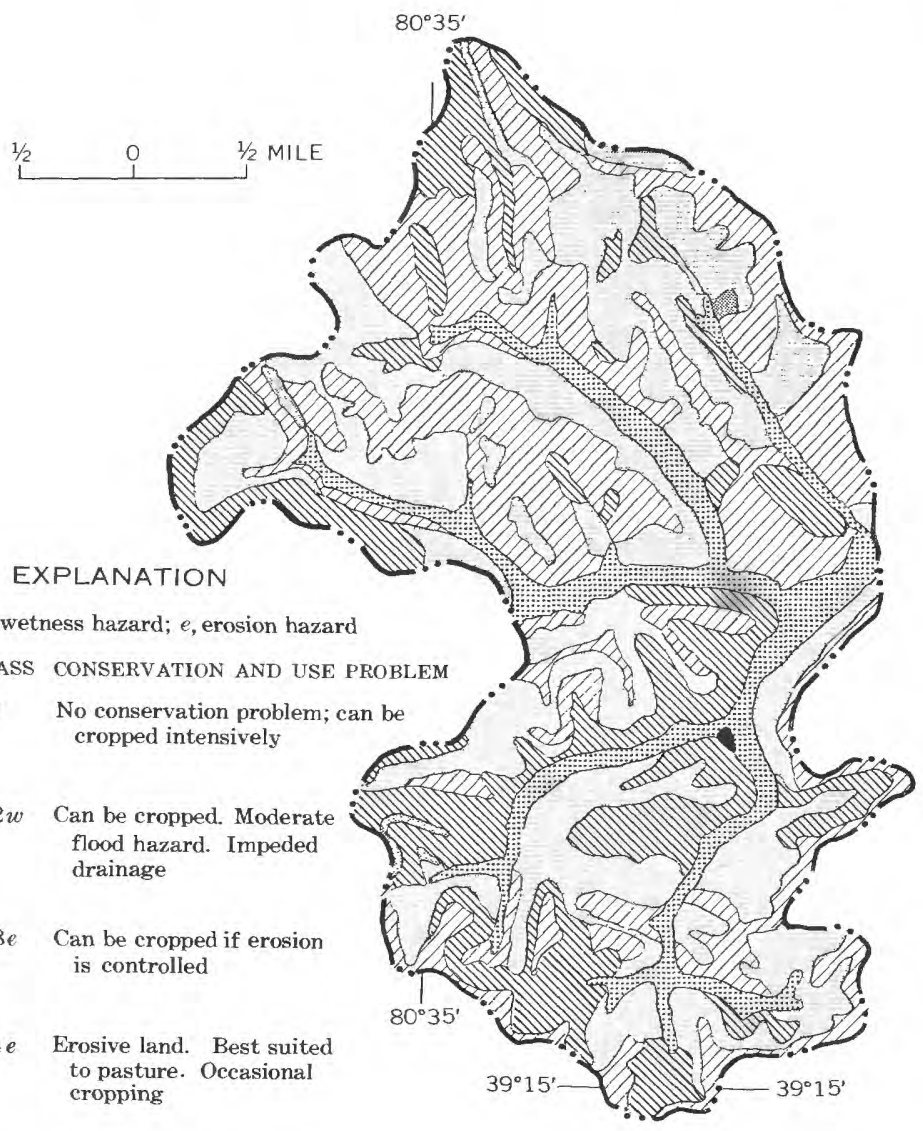

$w$, flood or wetness hazard; $e$, erosion hazard

SYMBOL CLASS CONSERVATION AND USE PROBLEM
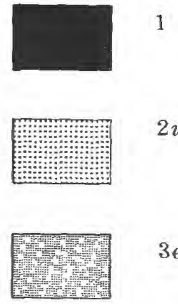

3e Can be cropped if erosion is controlled

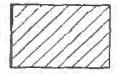

$6 e$ Steep land. Best kept in pasture or forest

$7 e \quad$ Very steep land or badly eroded.

Should be kept in forest 
cropping, but most of this land had flood or wetness and erosion hazards, denoted by subclasses $w$ and $e$, respectively (Buckman and Brady, 1960, p. 333). Class $4 e$ included 34 percent of the land and could be used for occasional cropping though it was erosive and recommended for pasture. The 39 percent of the land in class $6 e$ was steep and best suited to pasture or forest. The remaining 18 percent of the area was steep or badly eroded land in class $7 e$ and was recommended for forest only (U.S. Dept. Agriculture, 1954, p. 2).

Dairying and beef production are the chief enterprises of the grassland farming that is carried out in the area. The hillsides tend to be overgrazed since bottom lands are reserved principally for hay crops (U.S. Dept. Agriculture, 1954, p. 3). Some pasturing is allowed in the bottom lands during selected seasons of the year.

\section{HYDRAULIC STRUCTURES}

Seven of the eight detention structures shown in figure 1 were built for flood control. The structure on Dog Run, completed in November 1954 by the city of Salem to impound water for municipal water supply, has a limited flood-control capability.

The principal detention structure with which this report deals is that of reservoir 11A, on Varner Hollow Run. Storage in reservoir 11A began in 1954 when the earth dam was completed. The structure detains runoff from a drainage area of 184 acres $(0.288 \mathrm{sq} \mathrm{mi})$. At the time of its completion, reservoir $11 \mathrm{~A}$ had a storage capacity of 53.00 acre-feet and a surface area of 6.75 acres at the crest of the emergency spillway (elev 1,145.6 ft above mean sea level). The permanent (sediment) pool had an area of 0.92 acre and a capacity of 7.05 acre-feet at elevation $1,132.7$ feet. The reservoir is 211 feet wide and 1,390 feet long (U.S. Dept. Agriculture, 1970). Table 1 gives the stage and capacity of reservoir $11 \mathrm{~A}$ for 1 -foot increments of elevation.

The outlet structure of reservoir $11 \mathrm{~A}$ (fig. 5) consists of a 3 foot-square concrete drop inlet which is 17 feet in depth and connects to a 24-inch steel outlet pipe. A 12-inch horizontal steel pipe serves as a low-stage outlet which carries the flow from the reservoir to the drop inlet. An emergency earth spillway, 44 feet wide, is at the left end of the dam (fig. 6).

Reservoir 9 (see fig. 2) is on West Branch Patterson Fork in the southwestern part of the Salem Fork basin. The detention structure was completed and storage began in January 1956. The structure detains runoff from a drainage area of 590 acres $(0.92 \mathrm{sq} \mathrm{mi})$. As calculated from a survey made in November 1956, reservoir 9 had a storage capacity of 180.72 acre-feet at the 
crest of the emergency spillway (elev 1,105.1 ft above mean sea level). The permanent (sediment) pool had a capacity of 19.07 acre-feet at elevation 1,088.1 feet. Table 2 gives the capacity of reservoir 9 for 1 -foot increments of elevation.

The outlet structure of reservoir 9 consists of a 3-foot-square concrete drop inlet which connects to a 24 -inch steel outlet pipe.

TABLE 1. - Stage and capacity of reservoir $11 \mathrm{~A}$ from survey made in the fall of 1954

\begin{tabular}{cccc}
\hline $\begin{array}{c}\text { Gage } \\
\text { height } \\
\text { (feet) }\end{array}$ & $\begin{array}{c}\text { Elevation } \\
\text { (feet above } \\
\text { mean sea level) }\end{array}$ & $\begin{array}{c}\text { Capacity } \\
\text { (acre-feet) }\end{array}$ & Remarks \\
\hline 0.00 & $1,127.18$ & 0.28 & Datum of gage. \\
.82 & 1,128 & .67 & \\
1.82 & 1,129 & 1.60 & \\
2.82 & 1,130 & 2.78 & \\
3.82 & 1,131 & 4.18 & \\
4.82 & 1,132 & 5.76 & \\
5.52 & $1,132.7$ & 7.05 & \\
5.82 & 1,133 & 7.55 & \\
6.82 & 1,134 & 9.44 & \\
7.82 & 1,135 & 11.50 & \\
8.82 & 1,136 & 13.82 & \\
9.82 & 1,137 & 16.45 & \\
10.82 & 1,138 & 19.09 & \\
11.82 & 1,139 & 22.05 & \\
12.82 & 1,140 & 25.66 & \\
13.72 & $1,140.9$ & 29.40 & \\
13.82 & 1,141 & 29.80 & \\
14.82 & 1,142 & 33.83 & \\
15.82 & 1,143 & 38.40 & \\
16.82 & 1,144 & 43.59 & \\
17.82 & 1,145 & 49.30 & \\
18.42 & $1,145.6$ & 53.00 & \\
\hline
\end{tabular}

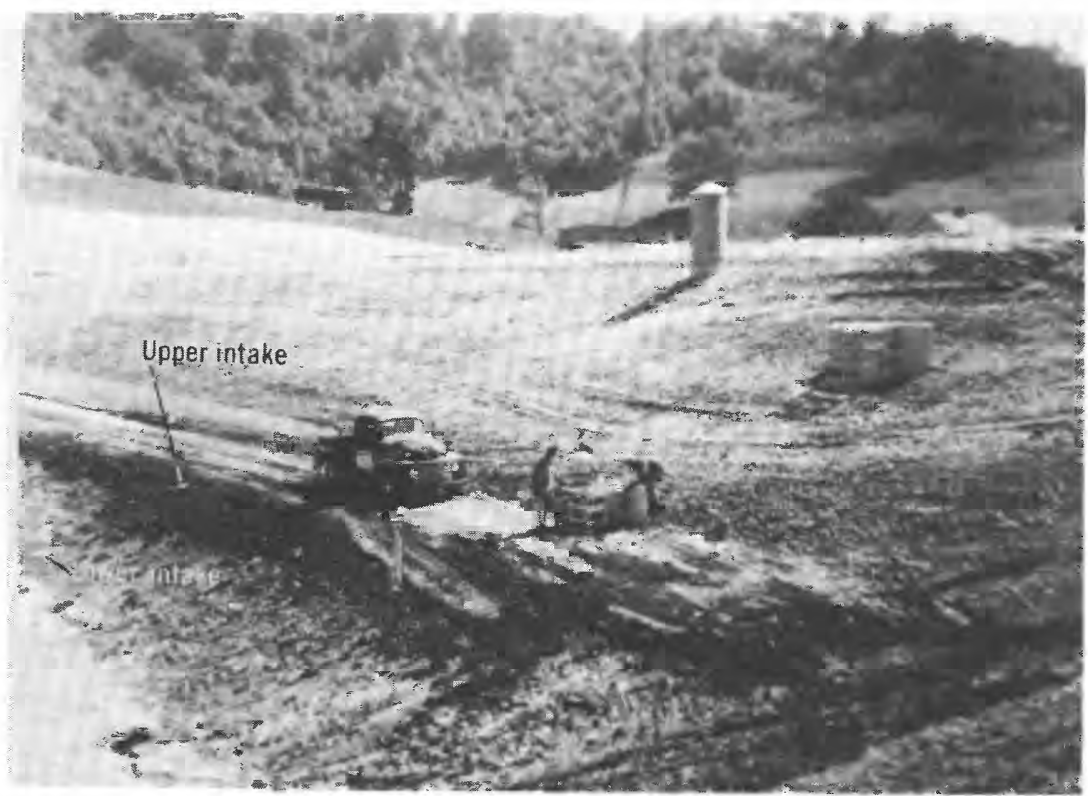

Figure 5. - View of upstream face of detention dam of reservoir 11A, showing outlet works (middleground), stage-recorder house (background), and gage-well intakes (foreground). Photograph by C. R. Collier. 


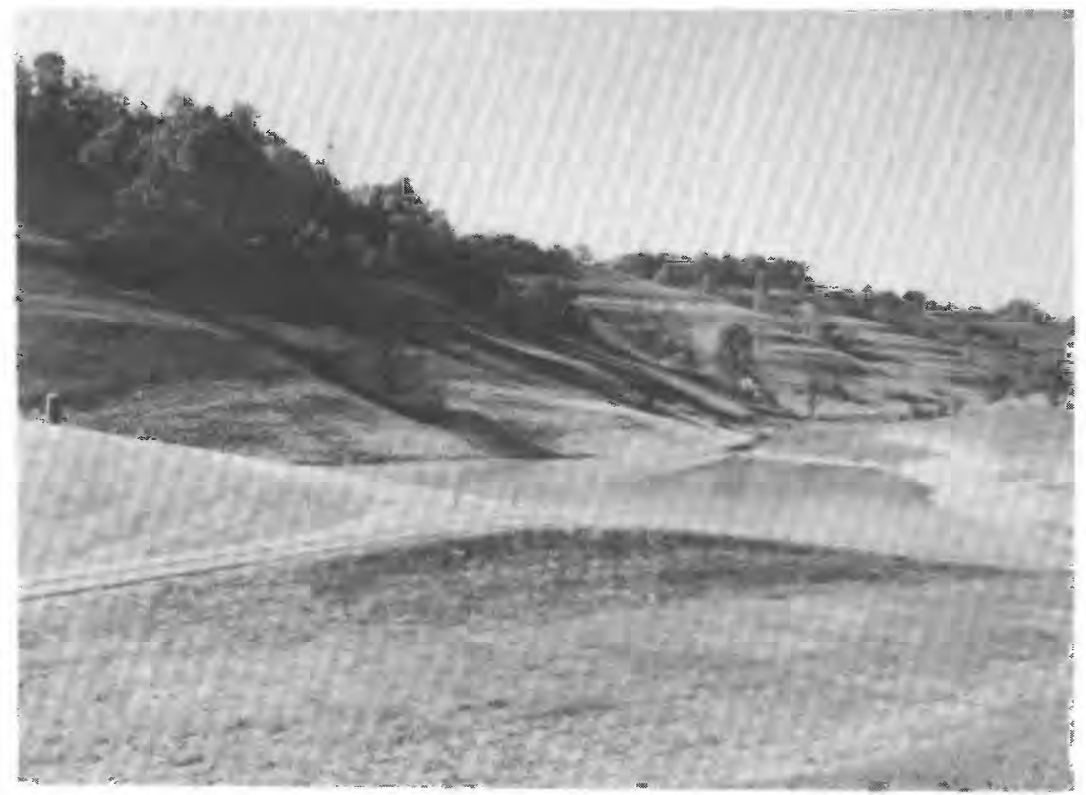

FIGURE 6. - View of reservoir 11A, showing part of emergency spillway (right foreground). Photograph by Soil Conservation Service.

TABLE 2. - Stage and capacity of reservoir 9 from survey made in November 1956

\begin{tabular}{|c|c|c|c|}
\hline $\begin{array}{l}\text { Gage } \\
\text { height } \\
\text { (feet) }\end{array}$ & $\begin{array}{c}\text { Elevation } \\
\text { (feet above } \\
\text { mean sea level) }\end{array}$ & $\begin{array}{c}\text { Capacity } \\
\text { (acre-feet) }\end{array}$ & Remarks \\
\hline 0.00 & $1,079.80$ & 0.40 & Datum of gage. \\
\hline .20 & $1,080^{\circ}$ & $\begin{array}{r}.80 \\
.59\end{array}$ & \\
\hline 1.20 & 1,081 & 1.60 & \\
\hline 2.20 & 1,082 & 3.07 & \\
\hline 3.20 & 1,083 & 5.15 & \\
\hline 4.20 & 1,084 & 7.51 & \\
\hline 5.20 & 1,085 & 10.00 & \\
\hline 6.20 & 1,086 & 12.72 & \\
\hline 7.20 & 1,087 & 15.70 & \\
\hline 8.20 & 1,088 & 18.76 & \\
\hline 8.30 & $1,088.1$ & 19.07 & Level of 16 -inch outlet pipe. \\
\hline 9.20 & 1,089 & 22.05 & \\
\hline 10.20 & 1,090 & 25.88 & . \\
\hline 11.20 & 1,091 & 30.10 & \\
\hline 12.20 & 1,092 & 35.51 & \\
\hline 13.20 & 1,093 & 41.25 & \\
\hline 14.20 & 1,094 & 48.10 & \\
\hline 15.20 & 1,095 & 55.50 & \\
\hline 16.20 & 1,096 & 64.06 & \\
\hline 17.20 & 1,097 & 73.60 & \\
\hline 18.20 & 1,098 & 83.71 & \\
\hline 19.20 & 1,099 & 94.00 & \\
\hline 20.20 & 1,100 & 105.01 & \\
\hline 21.20 & 1,101 & 117.80 & \\
\hline 22.20 & 1,102 & 131.63 & \\
\hline 23.20 & 1,103 & 146.50 & \\
\hline 24.20 & 1,104 & 162.15 & Level of principal spillway. \\
\hline 25.20 & 1,105 & 179.00 & \\
\hline 25.30 & $1,105.1$ & 180.72 & Level of emergency spillway. \\
\hline
\end{tabular}

A 16-inch horizontal steel pipe serves as a low-stage outlet and connects the reservoir with the drop inlet. An emergency spillway is at the right end of the dam. 
There is a total capacity of 376 acre-feet below the emergency spillways of the seven flood-control reservoirs of the watershed. In addition, the municipal reservoir on Dog Run has a capacity of 155 acre-feet.

\section{RUNOFF}

Outflow from the Salem Fork study area was determined from gaging-station records at Salem Fork at Salem. (See fig. 1.) Flow from 1,498 of the total 5,325 acres of the area was partly controlled by seven floodwater-detention reservoirs. The municipal reservoir on Dog Run exerts a slight additional control over the flow from its 566-acre drainage area.

Gaging-station records at the outlets of reservoirs $11 \mathrm{~A}$ and 9, shown on figure 1 , were the bases for computations of outflow from their corresponding subwatersheds.

Records of streamflow for the period October 1954 to September 1962 for Salem Fork at Salem and for reservoirs 11A and 9 are published in U.S. Geological Survey water-supply papers (U.S. Geol. Survey, 1957; 1958; 1959; 1960a, b; and 1961a) and in basic-data releases entitled "Surface Water Records of West Virginia" for water years 1961 and 1962 (available from the U.S. Geol. Survey, Charleston, W. Va.). Summaries of water discharge and other hydrologic data pertaining to the two reservoir stations and for Salem Fork at Salem are given in table 3. Total inflow to and runoff from the two reservoirs have been computed and are also included in table 3.

The average annual inflow to reservoir $11 \mathrm{~A}$ was 20.5 inches during a 7.75-year period. During this same period, the average annual runoff for Salem Fork at Salem was 21.6 inches. The average annual inflow to reservoir 9 was 23.6 inches, compared with an average annual runoff of 22.1 inches for Salem Fork at Salem during the 6.5-year period of record. The computed inflow values for both reservoirs compared favorably with the runoff values of the entire watershed as measured at Salem Fork at Salem.

\section{FLUVIAL SEDIMENT}

Fluvial sediment can be divided into two general classes, bedload and suspended load. Bedload is sediment that moves along and stays in almost continuous contact with the streambed. Suspended sediment is either colloidally suspended or held in suspension owing to upward components of turbulence.

The suspended-sediment discharge of a stream depends chiefly upon the physical characteristics of the drainage basin and the 
hydraulic characteristics of the stream. Precipitation intensityduration relations, the erodibility and transportability of soil material, land use, and topography affect the amounts of sediment delivered from an area. The nature of the fluvial-sediment study in the Salem Fork watershed did not afford an opportunity to evaluate the importance of each of the above factors but only the net effect of all factors. The effects of some of the individual factors were observed in the course of the study, however.

For the reservoir outflows, the entire depth of the flow was sampled at the outlet pipes; thus the total sediment discharge was represented by these samples. Because the sand fraction, some coarse silts, and some flocculated fine sediments were deposited in the reservoirs, sediment discharges at the reservoir outflow stations did not reflect the total sediment delivered from their watersheds.

For Salem Fork at Salem, nearly all the sediment moved as suspended sediment. Therefore, the records of suspended sedi-

TABLE 3. - Water discharge and miscellaneous reservoir computations, subwatersheds $11 A$ and 9 and Salem Fork at Salem

\begin{tabular}{|c|c|c|c|}
\hline & $\begin{array}{l}\text { ubwatershed } \\
11 \mathrm{~A}\end{array}$ & $\begin{array}{c}\text { Subwatershed } \\
9\end{array}$ & $\begin{array}{l}\text { Salem Fork } \\
\text { at Salem }\end{array}$ \\
\hline \multicolumn{4}{|c|}{ Water discharge, in acre-feet, for the indicated water year } \\
\hline $1955 \ldots$ & 297.1 & & 9,823 \\
\hline $1956 \ldots$ & 382.2 & 11,264 & 11,290 \\
\hline $1957 \ldots$ & 251.8 & 968 & 7,840 \\
\hline $1958 \ldots$ & 405.1 & 1,415 & 11,552 \\
\hline 1959 & 216.9 & 794 & 6,858 \\
\hline 1960 & 303.4 & 1,097 & 9,053 \\
\hline 1961 & 304.2 & 1,054 & 9,378 \\
\hline 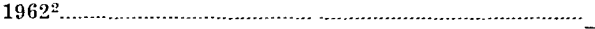 & 281.1 & 953 & 8,432 \\
\hline (n) & $2,441.8$ & 7,545 & 74,226 \\
\hline \multicolumn{4}{|c|}{ Precipitation, in inches, for the indicated water year } \\
\hline (1) & 43.03 & & 43.03 \\
\hline $1956^{4}$ & 57.16 & 149.89 & 57.16 \\
\hline $1957^{3} \ldots$ & 33.90 & 33.90 & 33.90 \\
\hline $1958^{\circ} \ldots$ & 55.79 & 55.79 & 55.79 \\
\hline $1959^{\circ} \ldots$ & 36.19 & 36.19 & 36.19 \\
\hline $1960^{\circ} \ldots$ & 47.79 & 47.79 & 47.79 \\
\hline $1961^{5} \ldots$ & 41.92 & 41.92 & 41.92 \\
\hline $1962=5$ & $31.5 \overline{8}$ & 31.58 & 31.58 \\
\hline Total & 347.36 & 297.06 & 347.36 \\
\hline \multicolumn{4}{|c|}{ Miscellaneous reservoir computations, $1954-62$} \\
\hline Drainage area................................................................acres... & 184 & 590 & 5,325 \\
\hline 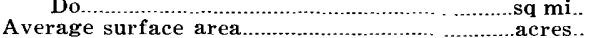 & $\begin{aligned} .288 \\
181\end{aligned}$ & $\begin{array}{r}.92 \\
3.54\end{array}$ & 8.32 \\
\hline Estimated evaporation from surface ${ }^{6} \ldots . . .$. acre-feet & 35 & $57^{0.07}$ & (n......... \\
\hline 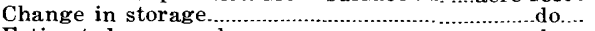 & +6 & +19 & ........... \\
\hline 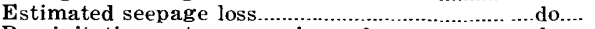 & 3 & 6 & ......... \\
\hline Precipitation onto reservoir surface................... do.... & 52 & 88 & ......... \\
\hline 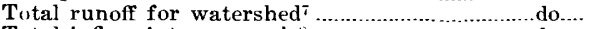 & 2,486 & 7,627 & ......... \\
\hline 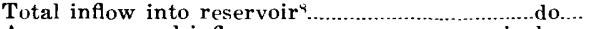 & 2,434 & 7,539 & ......... \\
\hline 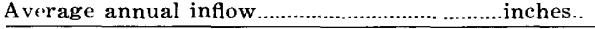 & 20.5 & 23.6 & .......... \\
\hline
\end{tabular}

1Period from January to September only.

2Period from October to June only.

${ }^{3}$ Average of totals for Clarksburg and Smithburg (U.S. Dept. Commerce, 1965).

iSalem official rain gage, unpublished data.

5Salem Post-Rogers official rain gage (U.S. Dept. Commerce, 1957-62).

${ }^{6}$ Based on pan-evaporation data at Clarksburg (U.S. Dept. Commerce, 1965) and on information from Kohler, Nordenson, and Baker (1959).

7Total runoff above dam $=$ outflow from reservoir + evaporation from reservoir surface + estimated seepage loss + change in storage during period.

${ }^{8}$ Inflow $=$ total runoff - precipitation on reservoir surface. 
ment were considered as the total load, and no adjustments were made for bedload.

Depth-integrated stream samples, collected by standard samplers, were analyzed in the laboratory to obtain the suspendedsediment concentration. Particle-size determinations for selected suspended-sediment samples were made by sieve-sedimentation methods or by sedimentation methods alone. Sedimentation methods are based on the fall velocity of the particles. Suspendedsediment data collected at the three sediment stations are presented in the following three sections.

\section{RESERVOIR 11A}

\section{SUSPENDED SEDIMENT}

All discharge from reservoir $11 \mathrm{~A}$, which occurred 81 percent of the time, was through the outlet pipe (fig. 7) during the period of sediment record. Daily sediment discharges in excess of 500 pounds occurred on 163 days during the period of investigation, or 5.8 percent of the total time. For these days, sediment discharge totaled 357,266 pounds, or 78 percent of the total sediment discharge. Thus, 78 percent of the sediment discharge occurred during less than 6 percent of the period of investigation. Table 4 summarizes data for all outflow periods at reservoir $11 \mathrm{~A}$.

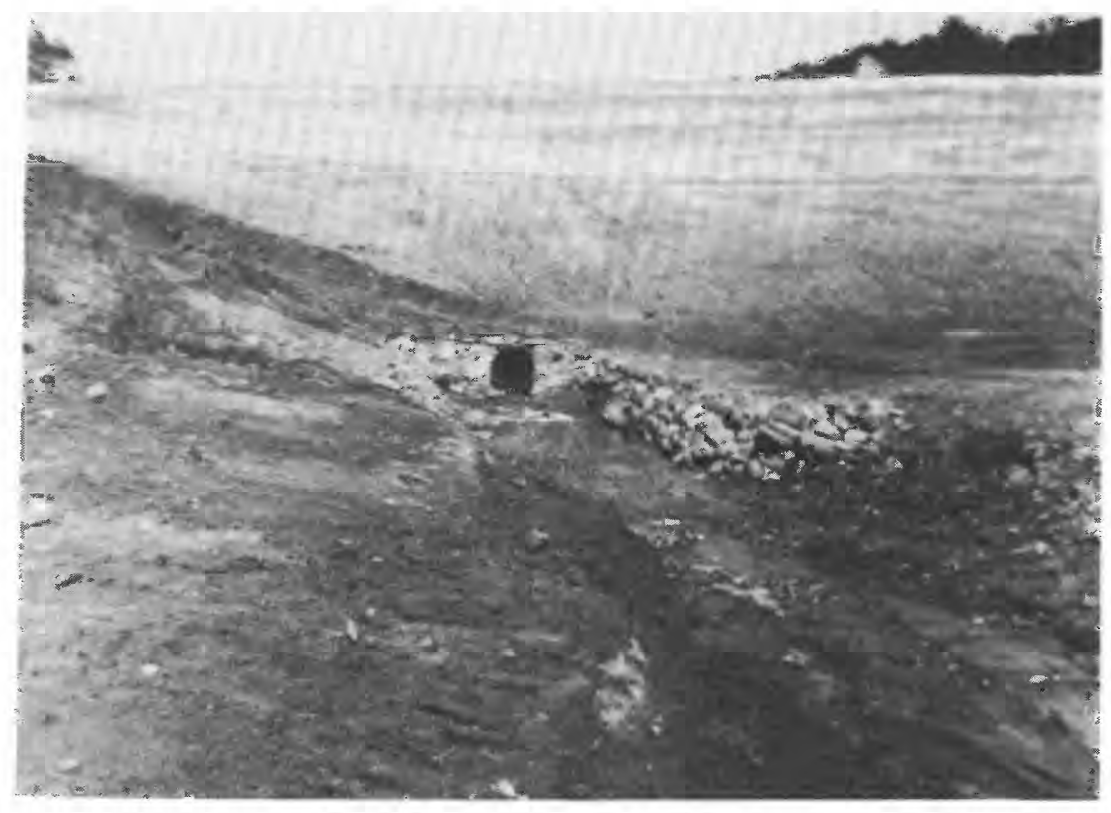

Figure 7. - Downstream face of dam of reservoir 11A, showing outlet pipe and riprap section. Photograph by C. R. Collier. 
TABLE 4. - Summary of outflow from reservoir 11A, 1954-62

[mg/l, milligrams per liter]

\begin{tabular}{|c|c|c|c|c|c|c|}
\hline \multirow{2}{*}{$\begin{array}{l}\text { Outflow } \\
\text { period }\end{array}$} & \multirow{2}{*}{$\begin{array}{l}\text { Total } \\
\text { days }\end{array}$} & \multicolumn{2}{|c|}{ Water discharge } & \multicolumn{2}{|c|}{$\begin{array}{l}\text { Sediment } \\
\text { discharge }\end{array}$} & \multirow{2}{*}{$\begin{array}{l}\text { Discharge- } \\
\text { weighted } \\
\text { suspended- } \\
\text { sediment } \\
\text { concentration } \\
(\mathrm{mg} / \mathrm{l})\end{array}$} \\
\hline & & $\begin{array}{l}\text { Cubic feet } \\
\text { per } \\
\text { second-days }\end{array}$ & Acre-feet & Pounds & Tons & \\
\hline Oct. $15,1954-$ May 25,1955 & 223 & 146.84 & 291.26 & 66,339 & 33 & 84 \\
\hline June $7-18,1955$ & 12 & .58 & 1.15 & 48 & .02 & 15 \\
\hline Aug. 22-Sept. 2, 1955 & 12 & 2.36 & 4.68 & 1,492 & .75 & 117 \\
\hline Oct. $7,1955-$ May $30,1957 \ldots .$. & 602 & 319.59 & 633.91 & 140,829 & $70^{\circ}$ & 82 \\
\hline Oct. $24,1957-$ May $27,1958 \ldots$ & 216 & 151.00 & 299.51 & 52,127 & 26 & 64 \\
\hline June 13-July 2,1958 & 20 & 1.79 & 3.55 & 433 & .22 & 45 \\
\hline July 6-Aug. 22, 1958 & 48 & 45.17 & 89.59 & 14,365 & 7.2 & 59 \\
\hline Aug. 24-Sept. 12, $1958 \ldots \ldots \ldots$. & 20 & 1.22 & 2.42 & 47 & .02 & 7 \\
\hline Sept. 17 -Oct. 21,1958 & 35 & 6.31 & 12.52 & 749 & .37 & 22 \\
\hline Oct. 26,1958 -June $10,1959 \ldots$. & 228 & 107.82 & 213.86 & 31,585 & 16 & 54 \\
\hline Aug. 9-14, 1959 & 6 & .28 & .56 & 17 & .01 & 11 \\
\hline Aug. $18-19,1959$ & 2 & .02 & .04 & 1 & & 9 \\
\hline Nov. $4,1959-J$ une $8,1960 \ldots$ & 218 & 125.04 & 248.02 & 33,322 & 17 & 49 \\
\hline June $12-18,1960$ & 7 & .46 & .91 & 13 & .01 & 5 \\
\hline June $21-28,1960$ & 8 & .33 & .65 & 8 & & 4 \\
\hline July $1-8,1960$ & 8 & .77 & 1.53 & 56 & .03 & 13 \\
\hline July $11-12,1960$ & 2 & .02 & .04 & 1 & & 9 \\
\hline July 14-Oct. 16,1960 & 95 & 26.60 & 52.76 & 10,319 & 5.2 & 72 \\
\hline Oct. $19,1960-J$ uly $1,1961 \ldots$ & 256 & 140.43 & 278.54 & 35,919 & 18 & 47 \\
\hline July $3-9,1961$ & 7 & .27 & .54 & 33 & .02 & 23 \\
\hline July 13-Aug. 29.1961 & 48 & 12.41 & 24.62 & 4,045 & 2.0 & 60 \\
\hline Oct. $5-9,1961$ & 5 & .08 & .16 & 5 & $\ldots$ & 12 \\
\hline Oct. $14-27,1961$ & 14 & .82 & 1.63 & 87 & .04 & 20 \\
\hline Oct. $31-$ Nov. 2,1961 & 3 & .05 & .10 & 3 & $\ldots$ & 11 \\
\hline Nov. $4,1961-$ May 14,1962 & 192 & 140.67 & 279.02 & 63,608 & 32 & 84 \\
\hline May $27-29,1962$ & 3 & .06 & .12 & 4 & $\ldots$. & 12 \\
\hline June $5-8,1962 \ldots \ldots \ldots \ldots \ldots$ & 4 & .10 & .20 & 6 & $\ldots$ & 11 \\
\hline June $11-13,1962$ & 3 & .04 & .08 & 2 & $\cdots$ & 9 \\
\hline Total & 2,297 & $1,231.13$ & $2,441.97$ & 455,463 & 227.89 & $\ldots .$. \\
\hline
\end{tabular}

Table 5, a summary of monthly water and sediment discharges from reservoir $11 \mathrm{~A}$, shows that 76 percent of the water and 78 percent of the sediment, on the average, were discharged during the 5-month period from December to April. At no time during December to April was flow interrupted. Flow usually persisted from October to May.

During the entire period of record for reservoir 11A, the discharge-weighted suspended-sediment concentration was about $69 \mathrm{mg} / \mathrm{l}$ (milligrams per liter). The maximum observed instantaneous concentration during the period of record was $626 \mathrm{mg} / \mathrm{l}$ on May 5, 1958. The maximum daily mean concentration during the period of record was $309 \mathrm{mg} / \mathrm{l}$ on December 30, 1954.

The maximum daily load during the period of record was 13,000 pounds on December 30, 1954. The maximum observed instantaneous suspended-sediment discharge of reservoir $11 \mathrm{~A}$ was 25,600 pounds per day on May 5, 1958.

Particle-size analyses of both the inflow and outflow samples from reservoir $11 \mathrm{~A}$ were made by standard sieve and sedimentation methods. The results of these analyses for the inflow and outflow of reservoir 11A are shown in tables 6 and 7, respectively. Inflow sediment averaged 51 percent clay $(0.0002-0.004 \mathrm{~mm}), 42$ percent silt $(0.004-0.062 \mathrm{~mm})$, and 7 percent sand $(0.062-2.00$ $\mathrm{mm})$. Outflow sediment averaged 81 percent clay and 19 percent silt and no sand. 


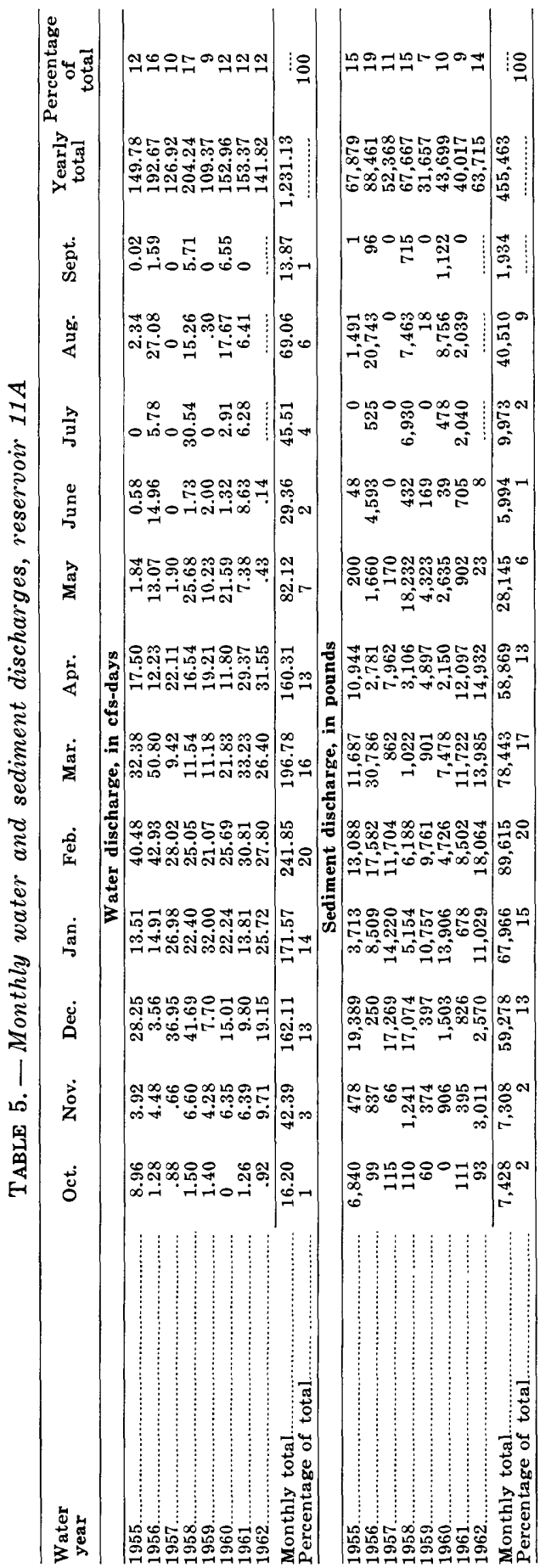




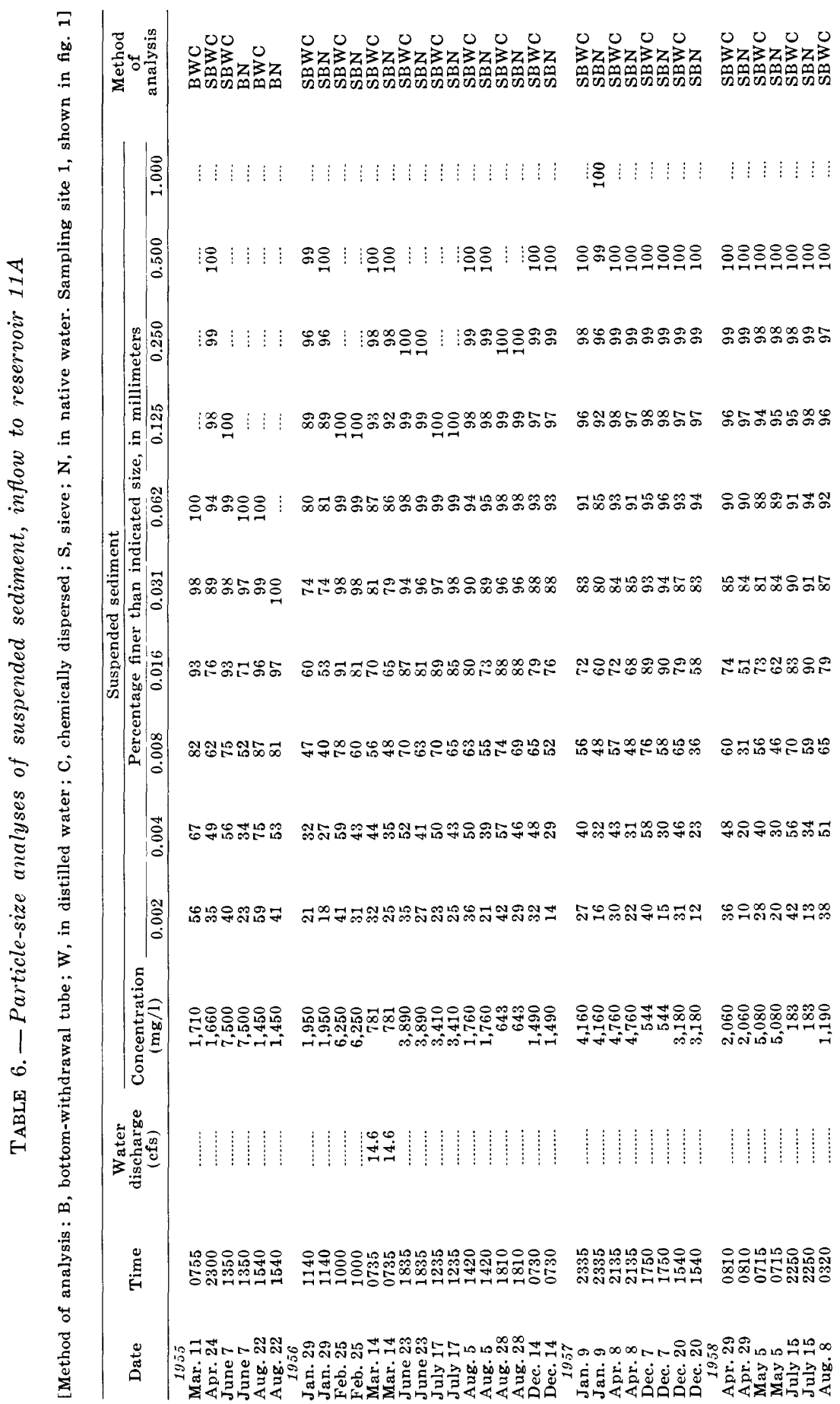




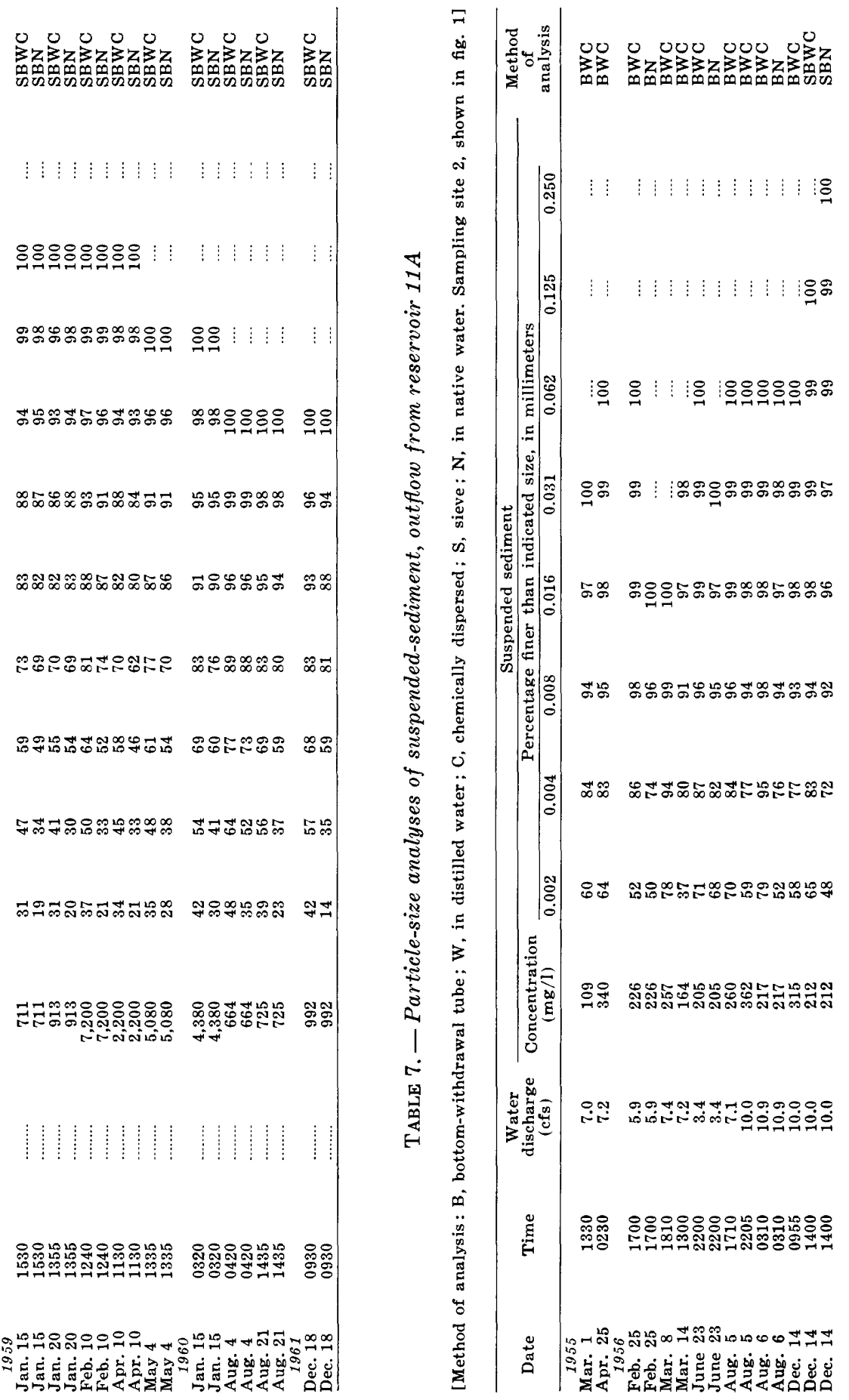




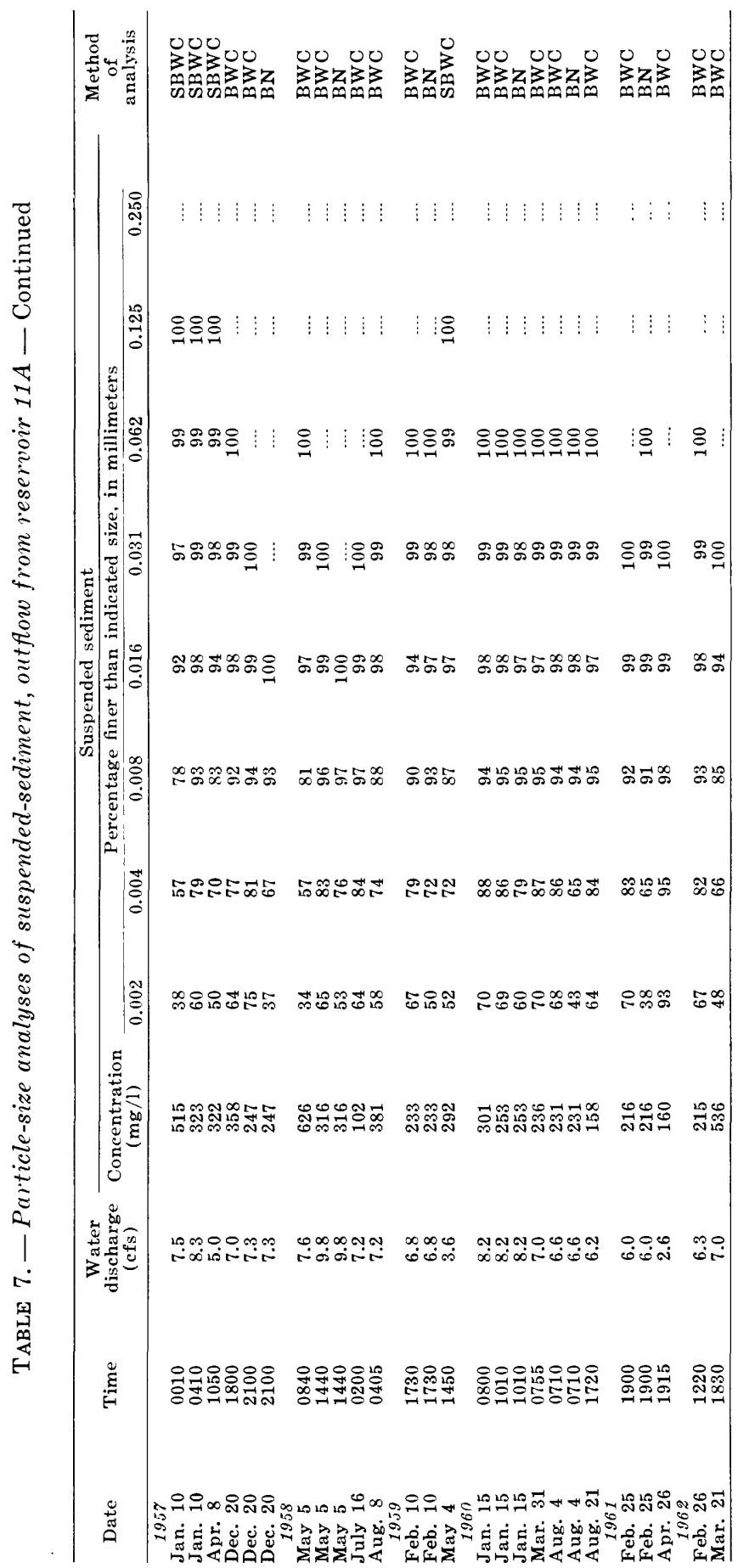


For practically all of the inflow samples and many of the outflow samples of reservoir $11 \mathrm{~A}$, particle-size distribution of the silt-clay fraction was determined in both distilled- and nativewater settling mediums. To determine the percentage distribution of the primary particles, a chemical dispersing agent was added to the distilled-water medium to cause deflocculation. Analyses were made of samples in the native-water medium to partially preserve the particle-size characteristics of the sediments, including the floccules of particles. Native-water analyses could then be used to predict the likelihood of flocculation and the settling characteristics of the sediments for the natural setting. These native-water analyses did show flocculation. The results of 26 pairs of analyses of inflow samples from reservoir $11 \mathrm{~A}$ in which both settling mediums were used showed an average of 15 percent less clay in the native-water settling medium than in the distilled-water medium.

A high calcium-sodium ratio in water causes flocculation of soil colloids, and a high sodium-calcium ratio causes dispersion of soil colloids (Rainwater and Thatcher, 1960, p. 127, 265). Chemical analyses of the inflow water of reservoir 11A (table 8) indicate an average calcium-sodium ratio of about $3: 1$; but, because calcium and sodium concentrations are extremely low, the ratio is probably insignificant relative to the flocculation of the sediments. Dissolved solids, calculated from conductance values $(0.6 \times$ conductance $)$, are low, ranging from 31 to $109 \mathrm{mg} / \mathrm{l}$ and averaging $49 \mathrm{mg} / \mathrm{l}$. The slightly acid condition of the water ( $\mathrm{pH}$ 6.4) may encourage some of the flocculation.

About the same degree of flocculation was detected in the particle-size analyses of outflow and inflow. Dissolved solids again averaged $49 \mathrm{mg} / \mathrm{l}$. The calcium-sodium ratio of $3.3: 1$ for the outflow was as insignificant as that for the inflow because concentrations of calcium and sodium were very low; the $\mathrm{pH}$ of the outflow was about equal to that of the inflow. Because natural conditions of temperature and turbulence cannot be duplicated in the laboratory, the degree of flocculation in the natural setting is uncertain.

\section{DEPOSITED SEDIMENT, TRAP EFFICIENCY, AND SEDIMENT YIELD}

Surveys of reservoir 11A, made by the Soil Conservation Service in October 1954, 1956, and 1958, December 1960, and June 1962 (U.S. Dept. Agriculture, 1970), consisted of 19 ranges across various parts of the reservoir. The original survey indicated a reservoir capacity of 53.00 acre-feet (below the emergency spillway); the capacity after the 1962 survey was 51.75 acre- 
feet. The 2.36-percent decrease in capacity was attributed to sediment deposition. The average dry weight per cubic foot of the deposited sediment was assumed to be 60 pounds (U.S. Dept. Agriculture, 1970). The computed weight of the sediment which accumulated during the 7.75-year period was 1,633 tons.

Listed in table 9 are sediment discharge, weight of deposited sediment, computed trap efficiency, and sediment yield during each of the periods between surveys of reservoir $11 \mathrm{~A}$. The high sediment yield of the first 2-year period was due largely to the high and continuous flow during the 1956 water year. During the 1955 and 1956 water years, 65 percent of the water and 73 percent of the sediment was discharged during December 1954, February and March 1955, and February, March, and August 1956. (See table 5.)

The trap efficiency, 88 percent, is about 3 percent below the estimated figure based on the capacity-inflow ratio method given by Brune (1953, p. 414). The capacity-inflow ratio used for reservoir $11 \mathrm{~A}$ was 0.169 .

\section{RESERVOIR 9, SUSPENDED SEDIMENT}

From January 1956 to June 1962 periodic suspended-sediment samples at Salem Fork subwatershed 9 (West Branch Patterson Fork) near Salem were collected to provide an index of the water-sediment discharge relationships and to provide data pertaining to the particle-size characteristics of the incoming and outgoing suspended sediment of the reservoir.

Instantaneous sediment discharges were computed for all samples taken at the outflow from reservoir 9. During most of the period, samples were collected too infrequently to make possible the computation of daily loads.

An average annual sediment discharge of 128,000 pounds per year was computed from measured flow-duration data for the outflow and from a computed curve showing the relation of instantaneous sediment discharge to instantaneous water discharge. This method was described by Jordan, Jones, and Petri (1964, p. 61-62). The curve rating instantaneous sediment discharge was applicable for all periods of outflow.

Particle size was analyzed for selected inflow and outflow samples. The limited data on inflow particle size suggest that the inflow contained up to 12 percent sand. The outflow contained an average of 20 percent silt and 80 percent clay and no sand. Particle-size analyses using native water and chemical analyses were not made for reservoir 9, but all particle-size analyses of suspended sediment for reservoir 9 are given in table 10 . 
TABLE 8. - Chemical analyses of water in Salem Fork basin

\begin{tabular}{|c|c|c|c|c|c|}
\hline $\begin{array}{c}\text { Date } \\
\text { of } \\
\text { collection }\end{array}$ & $\begin{array}{c}\text { Instantaneous } \\
\text { water } \\
\text { discharge } \\
(\mathrm{cfs})\end{array}$ & $\begin{array}{c}\text { Calcium, } \\
\mathrm{Ca} \\
(\mathrm{mg} / \mathrm{l})\end{array}$ & $\begin{array}{c}\text { Sodium, } \\
\mathrm{Na} \\
(\mathrm{mg} / 1)\end{array}$ & $\begin{array}{l}\text { Specific } \\
\text { conductance } \\
(\mathrm{micromhos} \\
\left.\text { at } 25^{\circ} \mathrm{C}\right)\end{array}$ & $\mathbf{p H}$ \\
\hline \multicolumn{6}{|c|}{ Reservoir 11A (sampling site 1 , shown in fig. 1 ) } \\
\hline $\begin{array}{lr}\text { June } & 7,1955 \\
\text { Aug. } 22,1955 \\
\text { Jan. } 29,1956 \\
\text { Feb. } 25,1956 \\
\text { Mar. } 14,1956 \\
\text { June } 23,1956 \\
\text { July } & 17,1956 \\
\text { Aug. } & 5,1956 \\
\text { Aug. } & 28,1956 \\
\text { Dec. } & 14,1956 \\
\text { Jan. } & 9,1957 \\
\text { Apr. } & 8,1957 \\
\text { Dec. } & 7,1957 \\
\text { Dec. } & 20,1957 \\
\text { Apr. } & 29,1958 \\
\text { May } & 5,1958 \\
\text { July } & 15,1958 \\
\text { Jan. } & 15,1959 \\
\text { Jan. } 20,1959 \\
\text { Feb. } & 10,1959 \\
\text { Apr. } & 10,1959 \\
\text { May } & 4,1959 \\
\text { Jan. } & 15,1960 \\
\text { Aug. } & 4,1960 \\
\text { Aug. } & 21,1960 \\
\text { Feb. } & 25,1961 \\
\text { Dec. } & 18,1961 \\
\text { Feb. } & 26,1962\end{array}$ & 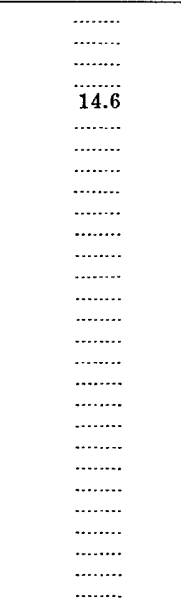 & $\begin{array}{c}4.8 \\
11 \\
6.7 \\
7.5 \\
4.9 \\
3.3 \\
3.3 \\
4.6 \\
6.8 \\
4.2 \\
7.6 \\
5.1 \\
8.6 \\
8.7 \\
14 \\
7.3 \\
6.8 \\
9.2 \\
6.9 \\
7.5 \\
6.4 \\
7.8 \\
9.0 \\
5.3 \\
5.2 \\
5.6 \\
7.8 \\
6.5\end{array}$ & $\begin{array}{r}4.1 \\
2.6 \\
2.6 \\
3.6 \\
1.5 \\
1.6 \\
3.1 \\
2.3 \\
2.4 \\
1.6 \\
2.3 \\
1.6 \\
1.8 \\
1.7 \\
2.4 \\
.8 \\
2.1 \\
2.6 \\
2.1 \\
2.1 \\
2.0 \\
3.2 \\
4.1 \\
.4 \\
\cdots .3 \\
3.2 \\
2.8\end{array}$ & $\begin{array}{r}79 \\
111 \\
96 \\
91 \\
59 \\
50 \\
58 \\
69 \\
82 \\
52 \\
59 \\
58 \\
93 \\
95 \\
182 \\
82 \\
86 \\
108 \\
80 \\
85 \\
75 \\
100 \\
81 \\
72 \\
69 \\
79 \\
90 \\
65\end{array}$ & $\begin{array}{l}6.6 \\
7.1 \\
6.5 \\
6.9 \\
7.1 \\
5.9 \\
6.1 \\
6.4 \\
7.2 \\
6.6 \\
6.8 \\
7.2 \\
6.3 \\
6.1 \\
4.3 \\
5.4 \\
7.1 \\
4.5 \\
5.9 \\
6.3 \\
7.0 \\
5.9 \\
5.5 \\
6.3 \\
6.1 \\
6.5 \\
7.5 \\
7.3\end{array}$ \\
\hline \multicolumn{6}{|c|}{ Reservoir 11A (sampling site 2, shown in fig. 1) } \\
\hline $\begin{array}{lrr}\text { Feb. } & 25,1956 \\
\text { June } & 23,1956 \\
\text { Aug. } & 6,1956 \\
\text { Dec. } & 14,1956 \\
\text { Dec. } & 20,1957 \\
\text { May } & 5,1958 \\
\text { Feb. } & 10,1959 \\
\text { Jan. } & 15,1960 \\
\text { Aug. } & 4,1960 \\
\text { Feb. } & 25,1961 \\
\end{array}$ & $\begin{array}{c}5.9 \\
3.4 \\
10.9 \\
10 \\
7.3 \\
9.8 \\
6.8 \\
8.2 \\
6.6 \\
6.0\end{array}$ & $\begin{array}{r}6.0 \\
7.6 \\
5.2 \\
6.2 \\
6.7 \\
6.0 \\
6.5 \\
8.4 \\
9.5 \\
10\end{array}$ & $\begin{array}{r}2.7 \\
2.7 \\
2.2 \\
3.1 \\
2.3 \\
1.0 \\
2.5 \\
1.9 \\
.8 \\
2.8 \\
\end{array}$ & $\begin{array}{r}69 \\
84 \\
66 \\
76 \\
88 \\
66 \\
75 \\
77 \\
122 \\
100 \\
\end{array}$ & $\begin{array}{l}6.8 \\
6.8 \\
6.5 \\
6.9 \\
6.5 \\
6.0 \\
7.2 \\
6.6 \\
5.4 \\
7.1\end{array}$ \\
\hline \multicolumn{6}{|c|}{ Salem Fork (sampling site 5 , shown in fig. 1) } \\
\hline $\begin{array}{lr}\text { July } & 17,1955 \\
\text { Feb. } & 25,1956 \\
\text { Apr. } & 8,1957 \\
\text { Dec. } & 7,1957 \\
\text { May } & 5,1958 \\
\text { Feb. } & 10,1959 \\
\text { Jan. } & 15,1960 \\
\end{array}$ & $\begin{array}{r}72 \\
152 \\
231 \\
388 \\
916 \\
270 \\
302 \\
\end{array}$ & $\begin{array}{c}20 \\
7.1 \\
9.2 \\
7.1 \\
6.7 \\
11 \\
10\end{array}$ & $\begin{array}{r}21 \\
3.0 \\
2.0 \\
1.8 \\
1.6 \\
3.4 \\
3.5\end{array}$ & $\begin{array}{r}253 \\
81 \\
81 \\
78 \\
71 \\
108 \\
87 \\
\end{array}$ & $\begin{array}{l}7.6 \\
7.0 \\
7.2 \\
6.6 \\
6.8 \\
6.6 \\
6.4\end{array}$ \\
\hline
\end{tabular}

TABLE 9. - Sediment data for periods between surveys of reservoir $11 \mathrm{~A}$

\begin{tabular}{|c|c|c|c|c|c|c|c|}
\hline \multirow[b]{2}{*}{ Period } & \multirow[b]{2}{*}{$\begin{array}{c}\text { Number } \\
\text { of } \\
\text { years }\end{array}$} & \multicolumn{3}{|c|}{$\begin{array}{c}\text { Sediment load } \\
\text { (tons) }\end{array}$} & \multicolumn{3}{|c|}{$\begin{array}{c}\text { Sediment yield } \\
\text { (tons per year) }\end{array}$} \\
\hline & & $\begin{array}{l}\text { Dis- } \\
\text { charged } \\
\text { from } \\
\text { reser- } \\
\text { voir }{ }^{1}\end{array}$ & $\begin{array}{l}\text { Depos- } \\
\text { ited } \\
\text { in } \\
\text { reser- } \\
\text { voir }\end{array}$ & Total & $\begin{array}{c}\text { Trap } \\
\text { effi- } \\
\text { ciency } \\
\text { (per- } \\
\text { cent) }\end{array}$ & $\begin{array}{l}\text { Per } \\
\text { square } \\
\text { mile }\end{array}$ & $\begin{array}{l}\text { Per } \\
\text { acre }\end{array}$ \\
\hline 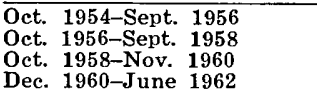 & $\begin{array}{l}2 \\
2 \\
2.17 \\
1.58\end{array}$ & $\begin{array}{l}78 \\
60 \\
38 \\
52 \\
\end{array}$ & $\begin{array}{l}980 \\
261 \\
131 \\
261 \\
\end{array}$ & $\begin{array}{r}1,058 \\
321 \\
169 \\
313 \\
\end{array}$ & $\begin{array}{l}93 \\
81 \\
78 \\
83 \\
\end{array}$ & $\begin{array}{r}1,843 \\
559 \\
271 \\
690 \\
\end{array}$ & $\begin{array}{r}2.88 \\
.87 \\
.42 \\
1.08\end{array}$ \\
\hline Oct. 1954-June 1962 & 7.75 & 228 & 1,633 & 1,861 & 88 & 837 & 1.31 \\
\hline
\end{tabular}

1Computed from table 5 .

2Based on an assumed average dry weight of 60 pounds per cubic foot of deposited sediment (U.S. Dept. Agriculture, 1970).

${ }^{3}$ Trap efficiency (percent) $=$ weight of deposited sediment (tons) $\times 100 \div$ weight of sediment (tons) delivered into reservoir.

${ }^{4}$ From contributing area of $0.287 \mathrm{sq} \mathrm{mi}$ (U.S. Dept. Agriculture, 1970). 


\section{SALEM FORK AT SALEM, SUSPENDED SEDIMENT}

Periodic records of suspended sediment were compiled for this location (see fig. 1) throughout the period from October 1954 to June 1962. Because more frequent sampling was carried on during the first 2 water years, 1955 and 1956, daily loads were determined. During periods of increased runoff, samples were collected more than once each day. During steady flow, samples were collected weekly. Instantaneous suspended-sediment discharge was determined for each sample.

The effects of intense storms that occur during the summer months were observed, to a degree, at this sediment station. The highest instantaneous concentration, $5,980 \mathrm{mg} / \mathrm{l}$, was measured June 7, 1955; the highest instantaneous suspended-sediment discharge, 10,500 tons per day, was measured August 22, 1955.

In analyzing sediment data for Salem Fork at Salem, the study period was divided into two periods, from October 1954 to September 1958 and from October 1958 to June 1962. During the first period, which was one of reservoir construction, conditions in the watershed were generally unstable, but during the second period, after completion of conservation measures, conditions in the watershed were fairly stable. A curve rating instantaneous suspended-sediment discharge for each of the two periods was plotted on the basis of average relations of instantaneous suspended-sediment discharge to water discharge (fig. 8). Average annual sediment discharges were determined for the two periods (Jordan and others, 1964) from flow-duration curves (fig. 9). The average annual sediment discharge for water years 1954-58 was 3,500 tons, adjusted by daily records collected from October 1954 to September 1956. During the second period, the average annual sediment discharge was 1,770 tons.

The average annual sediment discharge of 1,770 tons during the second period was only 51 percent of the adjusted average annual sediment discharge for the first period. Some of the factors contributing to the difference are as follows: (1) At the beginning of the first period, control or partial control of the flow from the watershed existed only on 899 of the 5,325 acres in the watershed, but during the second period, control or partial control had been increased to, and remained at, 2,064 acres, (2) construction activities in the watershed and the implementation of other conservation measures which were in progress during the first period were essentially complete at the beginning of the second period, (3) average annual rainfall was 8.1 inches higher for the first period than for the second, and (4) average annual runoff at the 
gaging station at Salem Fork at Salem was 3.8 inches higher for the first period than for the second. Neither the relative importance of the above factors nor the importance of other contributing factors was evaluated in this study.

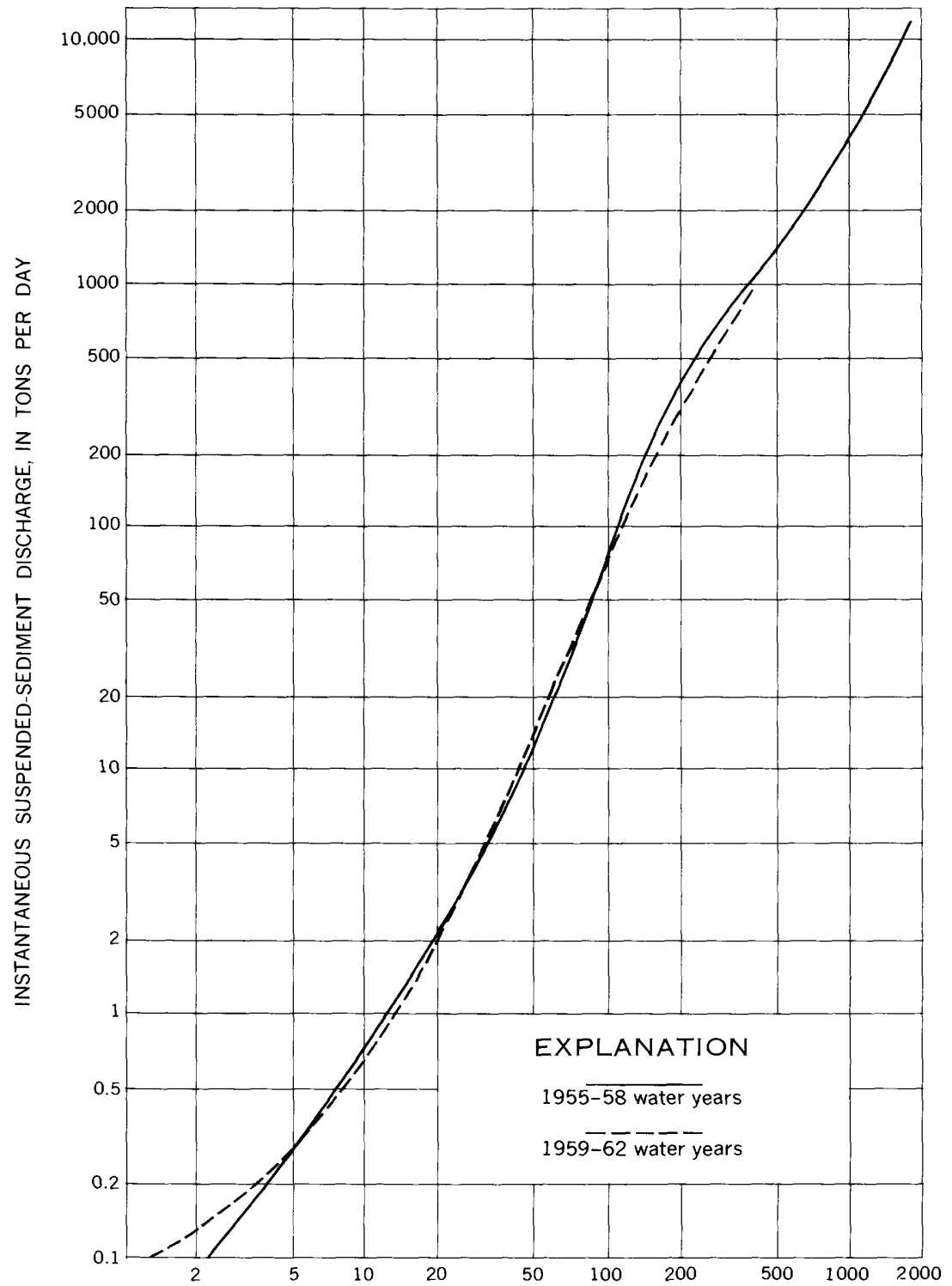

INSTANTANEOUS WATER DISCHARGE, IN CUBIC FEET PER SECOND

Figure 8. - Average relations of suspended-sediment discharge to water discharge, Salem Fork at Salem. 


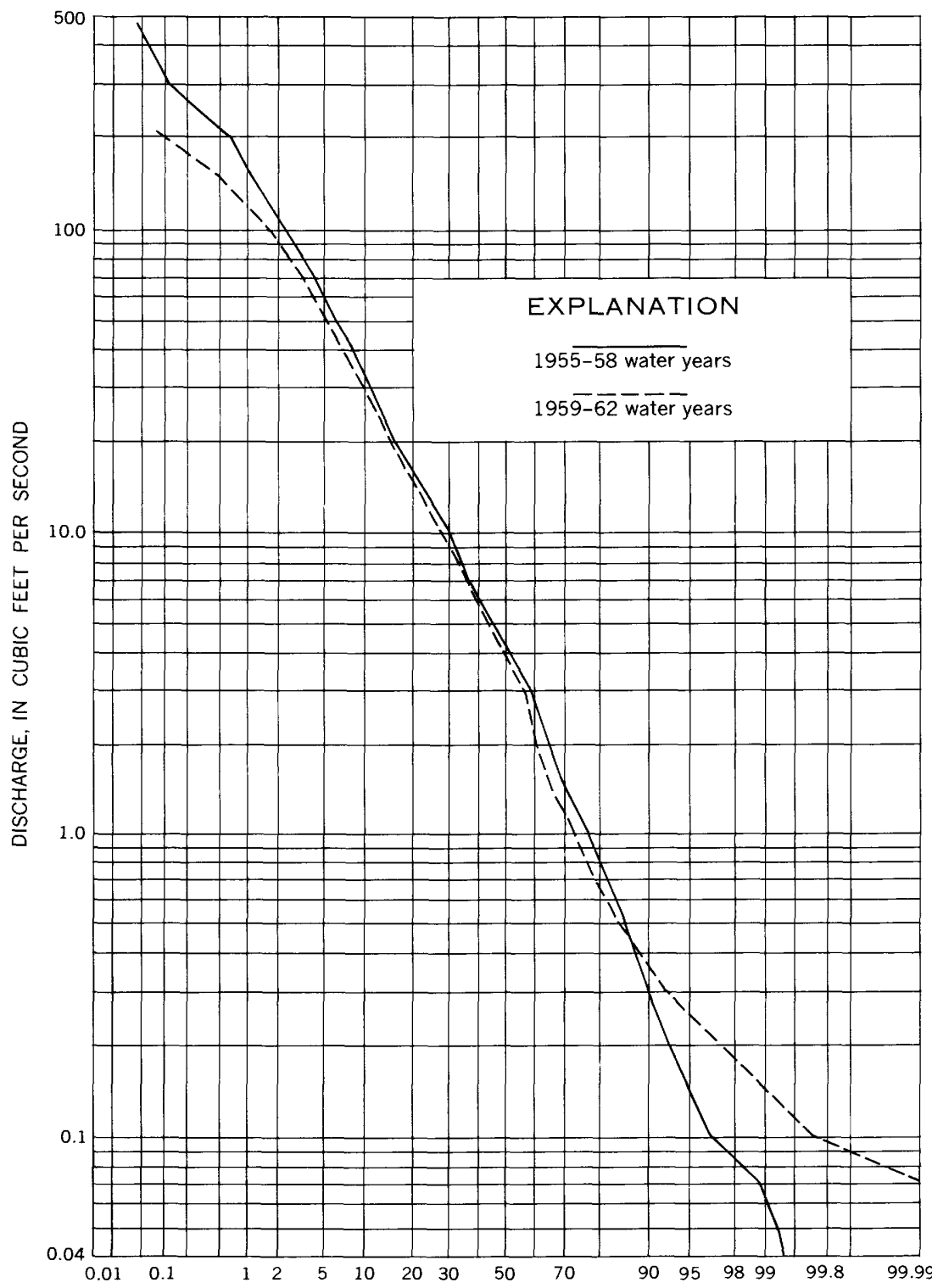

PERCENTAGE OF TIME INDICATED DISCHARGE WAS EQUALED OR EXCEEDED

Figure 9. - Duration curves of daily flow for the two 4-year periods of investigation, Salem Fork at Salem.

Particle-size analyses of the samples from the first period were compared with those from the second. There was no appreciable difference between the averages of the analyses for the two periods. 
Thus, although the amount of suspended sediment discharged was reduced following reservoir completion, the particle-size distribution of the suspended sediment carried past the main-channel station did not change. Particle-size analyses for Salem Fork at Salem are summarized in table 11.

Flow leaving the reservoirs was essentially free of sand; however, the capacity of the flow for carrying various sizes of particles did not decrease. Apparently, adjustments in particle-size distribution in the flow were made below the reservoirs by the entraining of available channel sediments above the Salem Fork station.

\section{CONCLUSIONS}

Investigations of runoff and fluvial sediment, made at three sites in the Salem Fork basin from October 1954 to June 1962, have resulted in the following conclusions:

1. Both water discharge and sediment discharge were significantly affected by upstream developments which began in October 1954.

2. Particle-size analyses of suspended sediment of the inflow and outflow from reservoirs $11 \mathrm{~A}$ and 9 indicated that sand delivered to the reservoirs was deposited in the reservoirs.

3. Clay and silt constituted the bulk of sediment discharged from reservoirs $11 \mathrm{~A}$ and 9 .

4. Laboratory analyses indicated that the native water of both inflow and outflow from reservoir $11 \mathrm{~A}$ was capable of causing flocculation of the clay. The degree of natural flocculation could not be determined from the data.

5. Average annual sediment discharge of 3,500 tons at Salem Fork at Salem during the unstable 4-year period from 1954 to 1958 was about twice the amount of 1,770 tons for the stable 4-year period from 1958 to 1962 . Factors which may have contributed to this difference during the latter period are (a) there was more control of the flow in the watershed resulting from completed detention structures and conservation measures, (b) there were fewer sediment-contributing construction activities, and (c) there was less rainfall and runoff than during the 1954-58 period.

6. Trap efficiency of reservoir $11 \mathrm{~A}$ for the period of investigation was 88 percent and ranged from 73 to 93 percent for periods between surveys.

7. The annual sediment yield of subwatershed $11 \mathrm{~A}$ for the entire period of investigation was 1.31 tons per acre. 
ก

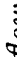

$\frac{3}{3}$

క్ర

+

3 0

.

芯

उ 3

ริ

5

స్త

-

|
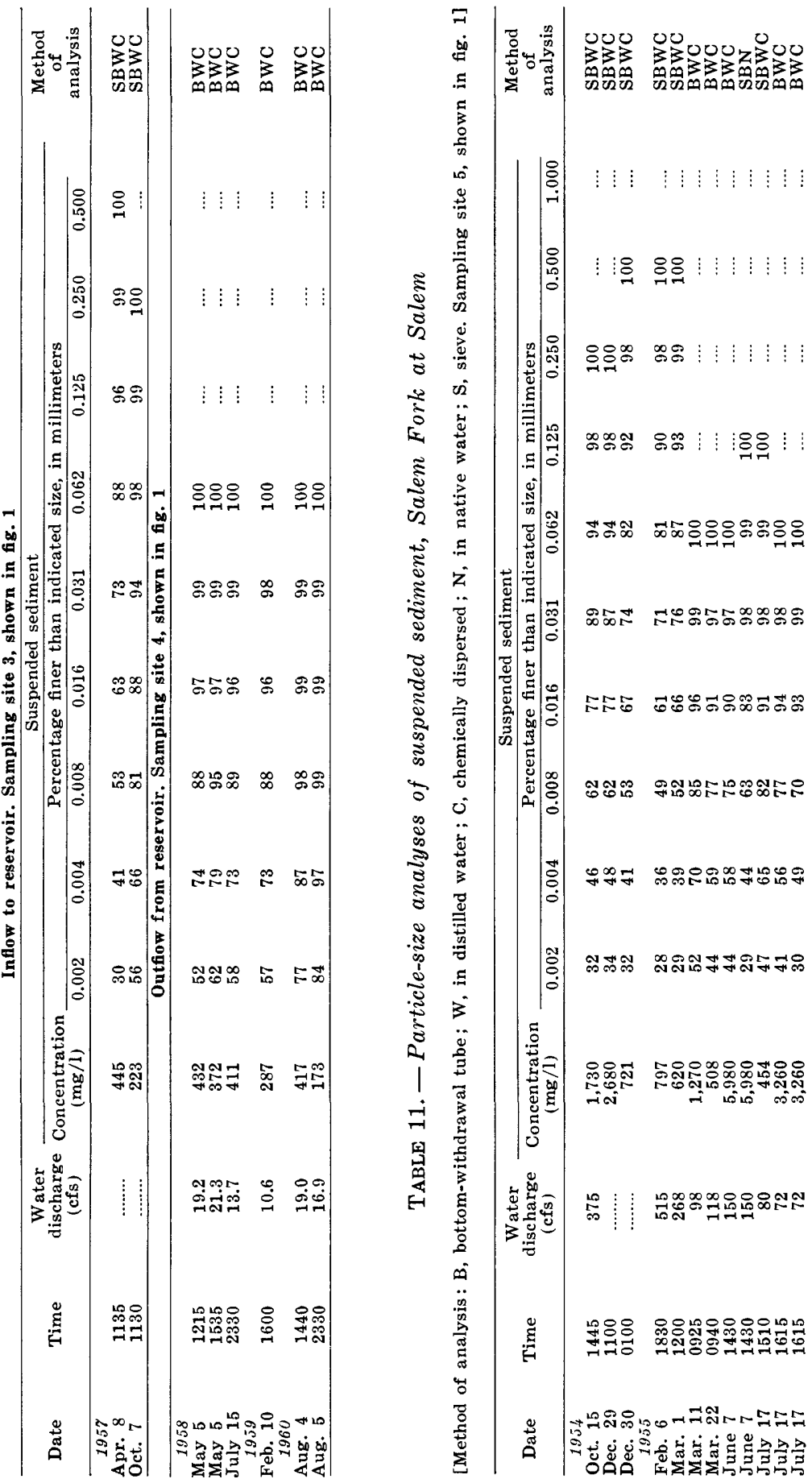


\begin{tabular}{|c|c|c|c|c|}
\hline 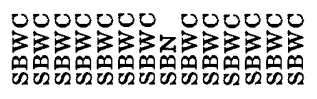 & 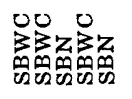 & 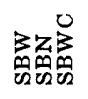 & 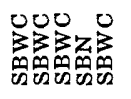 & 䓪 \\
\hline 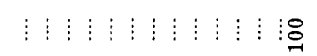 & 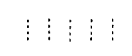 & $\vdots: \vdots \vdots$ & 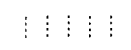 & $\vdots$ \\
\hline :@: : & : & ஓ: & 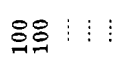 & $\vdots$ \\
\hline 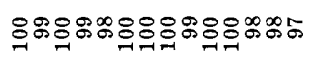 & ஜ৪ஃঞஃஃ & 됴요 & ৪৪৪০০ & $\stackrel{一}{-1}$ \\
\hline 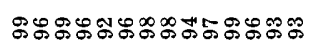 & ஓஃஃ8ஃ & ৪ภั & 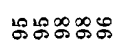 & $\mathscr{8}$ \\
\hline 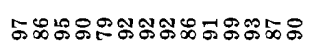 & 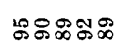 & வே゙ & 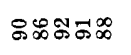 & $\infty$ \\
\hline 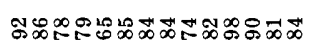 & 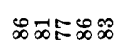 & : & 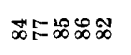 & $\stackrel{\infty}{\sim}$ \\
\hline 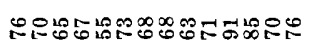 & Tละ8:88 & ๑ேષ & 요요요용 & $\therefore$ \\
\hline 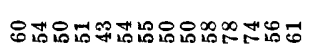 & ตำำำำำ & 脶눈 & 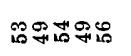 & 28 \\
\hline 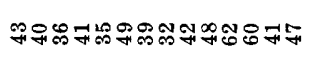 & 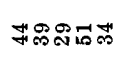 & 瓭品 & 구윰ํㅠ & 5 \\
\hline 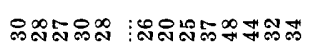 & 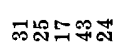 & సేన్ & 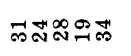 & $\ddot{\infty}$ \\
\hline 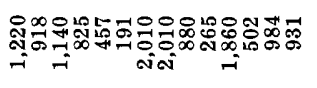 & 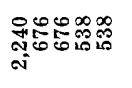 & 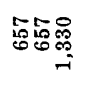 & 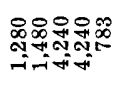 & 竎 \\
\hline 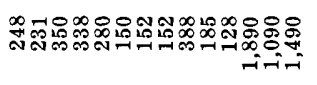 & 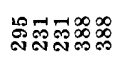 & 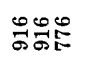 & 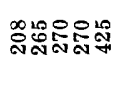 & \\
\hline 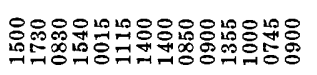 & 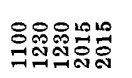 & 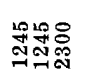 & 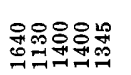 & $\stackrel{8}{\circ}$ \\
\hline
\end{tabular}




\section{REFERENCES}

Beverage, W. W., Steputis, W. J., and Hatfield, W. F., 1968, Soil survey of Barbour County, West Virginia: U.S. Dept. Agriculture Soil Survey Ser. $65 \mathrm{p}$.

Brune, G. M., 1953, Trap efficiency of reservoirs: Am. Geophys. Union Trans., v. 34, p. $407-418$.

Buckman, H. M., and Brady, N. C., 1960, The nature and properties of soils [6th ed.]: New York, The Macmillan Co., $567 \mathrm{p}$.

Fenneman, N. M., 1938, Physiography of the eastern United States: New York, McGraw-Hill Book Co., 714 p.

Gorman, J. L., and Rayburn, J. B., 1961, Soil survey of Jackson and Mason Counties, West Virginia: U.S. Dept. Agriculture Soil Survey Ser. 92 p.

Jordan, P. R., Jones, B. F., and Petri, L. R., 1964, Chemical quality of surface waters and sedimentation in the Saline River basin, Kansas: U.S. Geol. Survey Water-Supply Paper 1651, $90 \mathrm{p}$.

Kohler, M. A., Nordenson, T. J., and Baker, D. R., 1959, Evaporation maps for the United States: U.S. Dept. Commerce Tech. Paper 37, 13 p.

Mundorff, J. C., 1964, Fluvial sediment in Kiowa Creek basin, Colorado: U.S. Geol. Survey Water-Supply Paper 1798-A, 70 p.

Nace, R. L., and Bieber, P. O., 1958, Ground-water resources of Harrison County, West Virginia: West Virginia Geol. and Econ. Survey Bull. 14, $55 \mathrm{p}$.

Rainwater, F. H., and Thatcher, L. L., 1960, Methods for collection and analysis of water samples: U.S. Geol. Survey Water-Supply Paper 1454, 301 p.

Thornbury, W. D., 1954, Principles of geomorphology: New York, John Wiley \& Sons, Inc., $618 \mathrm{p}$.

U.S. Department of Agriculture, 1954, Work plan, Salem Fork watershed, Harrison County, West Virginia: $12 \mathrm{p}$.

1970, Reservoir sediment data summary, Salem Fork No. 11a: U.S. Soil Conservation Service, $4 \mathrm{p}$.

U.S. Department of Commerce, Hourly precipitation data, annual summaries for West Virginia, 1957-62: U.S. Weather Bur.

1965, Climatic summary of the United States, Numbers 86-40, Supplement for 1951 through 1960, West Virginia: U.S. Weather Bur., $54 \mathrm{p}$.

U.S. Geological Survey, 1957, Surface water supply of the United States 1955 - Part 3-A, Ohio River basin except Cumberland and Tennessee River basins: U.S. Geol. Survey Water-Supply Paper 1385, 581 p.

1958, Surface water supply of the United States 1956 - Part 3-A, Ohio River basin except Cumberland and Tennessee River basins: U.S. Geol. Survey Water-Supply Paper 1435, 561 p.

1959, Surface water supply of the United States 1957 - Part 3-A, Ohio River basin except Cumberland and Tennessee River basins: U.S. Geol. Survey Water-Supply Paper 1505, 553 p.

1960 a, Surface water supply of the United States 1958 - Part 3-A, Ohio River basin except Cumberland and Tennessee River basins: U.S. Geol. Survey Water-Supply Paper 1555, 574 p.

$1960 \mathrm{~b}$, Surface water supply of the United States 1959 - Part 3-A, Ohio River basin except Cumberland and Tennessee River basins: U.S. Geol. Survey Water-Supply Paper 1625, 565 p. 
1961a, Surface water supply of the United States 1960 - Part 3-A, Ohio River basin except Cumberland and Tennessee River basins: U.S. Geol. Survey Water-Supply Paper 1705, 583 p.

Weedfall, Robert O., [no date], Climate of Clarksburg, West Virginia: U.S. Dept. Commerce, ESSA, Climatic summary of the United States No. 20-46, 2 p.

White, I. C., 1883, Notes on the geology of West Virginia: The Virginias, v. 4, p. 123-126. 